\title{
Hydrological variability in the Northern Levant: a 250 ka multi- proxy record from the Yammoûneh (Lebanon) sedimentary sequence
}

\author{
F. Gasse ${ }^{1, * *}$, L. Vidal ${ }^{1}$, A.-L. Develle ${ }^{1, *}$, and E. Van Campo ${ }^{2,3}$ \\ ${ }^{1}$ CEREGE, UMR6635, Marseille Université-CNRS-IRD-Collège de France, BP 80, 13545 Aix-en-Provence cedex 04, France \\ ${ }^{2}$ Université de Toulouse, UPS, INPT, Ecolab, 29 rue Jeanne Marvig, 31055 Toulouse, France \\ ${ }^{3}$ CNRS, Ecolab (Laboratoire d'écologie fonctionnelle), 31055 Toulouse, France \\ *now at: Laboratoire Chrono-Environnement, UMR6249, Université de Franche-Comté, 16 Route de Gray, \\ 25030, Besançon cedex, France \\ ** Invited contribution by F. Gasse, recipient of the EGU Hans Oeschger Medal 2010
}

Received: 13 April 2011 - Published in Clim. Past Discuss.: 10 May 2011

Revised: 13 September 2011 - Accepted: 5 October 2011 - Published: 24 November 2011

\begin{abstract}
The Levant is a key region in terms of both long-term hydroclimate dynamics and human cultural evolution. Our understanding of the regional response to glacialinterglacial boundary conditions is limited by uncertainties in proxy-data interpretation and the lack of long-term records from different geographical settings.

The present paper provides a $250 \mathrm{ka}$ paleoenvironmental reconstruction based on a multi-proxy approach from northern Levant, derived from a $36 \mathrm{~m}$ lacustrine-palustrine sequence cored in the small intra-mountainous karstic Yammoûneh basin from northern Lebanon. We combined time series of sediment properties, paleovegetation, and carbonate oxygen isotopes $\left(\delta_{\mathrm{c}}\right)$, to yield a comprehensive view of paleohydrologic-paleoclimatic fluctuations in the basin over the two last glacial-interglacial cycles. Integration of all available proxies shows that Interglacial maxima (early-mid MIS 7, MIS 5.5 and early MIS 1) experienced relatively high effective moisture, evidenced by the dominance of forested landscapes (although with different forest types) associated with authigenic carbonate sedimentation in a productive waterbody. Synchronous and steep $\delta_{\mathrm{c}}$ increases can be reconciled with enhanced mean annual moisture when changes in seasonality are taken into account. During Glacials periods (MIS 2 and MIS 6), open vegetation tends to replace the forests, favouring local erosion and detrital sedimentation.
\end{abstract}

However, all proxy data reveal an overall wetting during MIS 6, while a drying trend took place during MIS4-2, leading to extremely harsh LGM conditions possibly linked to water storage as ice in the surrounding highlands. Over the past $250 \mathrm{ka}$, the Yammoûneh record shows an overall decrease in local effective water, coincident with a weakening of seasonal insolation contrasts linked to the decreasing amplitude of the eccentricity cycle.

The Yammoûneh record is roughly consistent with longterm climatic fluctuations in the northeastern Mediterranean region (except during MIS 6). It suggests that the role of seasonality on effective moisture, already highlighted for MIS 1, also explains older interglacial climate. The Yammoûneh record shares some features with speleothem isotope records of western Israel, while the Dead Sea basin generally evolved in opposite directions. Changes in atmospheric circulation, regional topographic patterns and site-specific hydrological factors are invoked as potential causes of spatial heterogeneities.

Further work is needed to refine the Yammoûneh chronology, better understand its functioning through hydrological and climate modelling, and acquire other long records from northern Levant to disentangle the relative effects of local versus regional factors.

\section{Correspondence to: F. Gasse}

(gasse@cerege.fr)

Published by Copernicus Publications on behalf of the European Geosciences Union. 


\section{Introduction}

The Levant (Fig. 1), which stretches along the East Mediterranean seashore from Southeast Turkey to northern Egypt and Arabia, straddles the boundary between a typical temperate-warm Mediterranean domain and the subtropical desertic belt. Moisture primarily comes from the eastern Mediterranean Sea (EMS). Rainfall decreases sharply from north to south with latitude and more sharply from west to east due to the orographic effect of mountain ranges running parallel to the coastline. Just eastward, a chain of deep depressions, including the Dead Sea basin, forms a narrow corridor. Altitudes range from more than $3000 \mathrm{~m}$ a.s.l. (above sea level) in Lebanon to $425 \mathrm{~m}$ b.s.l. (below sea level) along the Dead Sea shore. This complex physiogeographic pattern results in a large diversity of terrestrial environmental conditions which vary dramatically over short distances with latitude, altitude and continentality.

Numerous terrestrial and marine archives have revealed huge Late Quaternary climatic-hydrological fluctuations in the EMS domain. The northeastern Mediterranean region experienced wet-warm interglacials with intense rainfall from the North Atlantic and cold-dry glacial environments when ice sheets over northern Europe reached their maximal extension (e.g., Tzedakis, 2007), as showed, for example, by pollen-inferred reconstructions of climatic parameters (e.g., Guiot et al., 1999). Monsoonal rainfall penetrated the subtropical desertic belt during boreal summer insolation maximums (peak of Interglacials periods) while glacial stages were hyperarid, as revealed by speleothem, lake and groundwater archives (e.g., Gasse, 2000; Hoelzmann et al., 2004; Fleitmann and Matter, 2009).

Between these two domains, changes in water availability in the Levant, which might have influenced the migration of early modern humans out of Africa and the Pleistocene-Holocene cultural dynamics of Eurasia (BarYosef, 1998; Vaks et al., 2007; Shea, 2008; Carto et al., 2009; Frumkin et al., 2011), have been the focus of outstanding climatic-hydrological studies (see the reviews of Robinson et al., 2006; Enzel et al., 2008; Waldmann et al., 2010; Frumkin et al., 2011, and references therein). The best records come from U/Th-dated stable isotope profiles of Israeli speleothems and reconstructed lake-level fluctuations in the Dead-Sea basin (DSB). Long terrestrial pollen records are scarce and poorly dated (e.g., Bottema and Van Zeist, 1981; Weinstein-Evron, 1983; Weinstein-Evron et al., 2001; Meadows, 2005). In southern Levant, sporadic events of speleothems and travertine growth indicate episodes of enhanced effective precipitation in phase with periods of intensified monsoon (Waldmann et al., 2010; Vaks et al., 2010). Just northward, the DSB experienced generally high lake water levels indicating locally high effective moisture during glacial periods and dry conditions during Interglacials attributed to changes in rainfall amount by Enzel et al. (2008). Conversely, speleothems $\delta^{18} \mathrm{O}$ profiles from western Israel

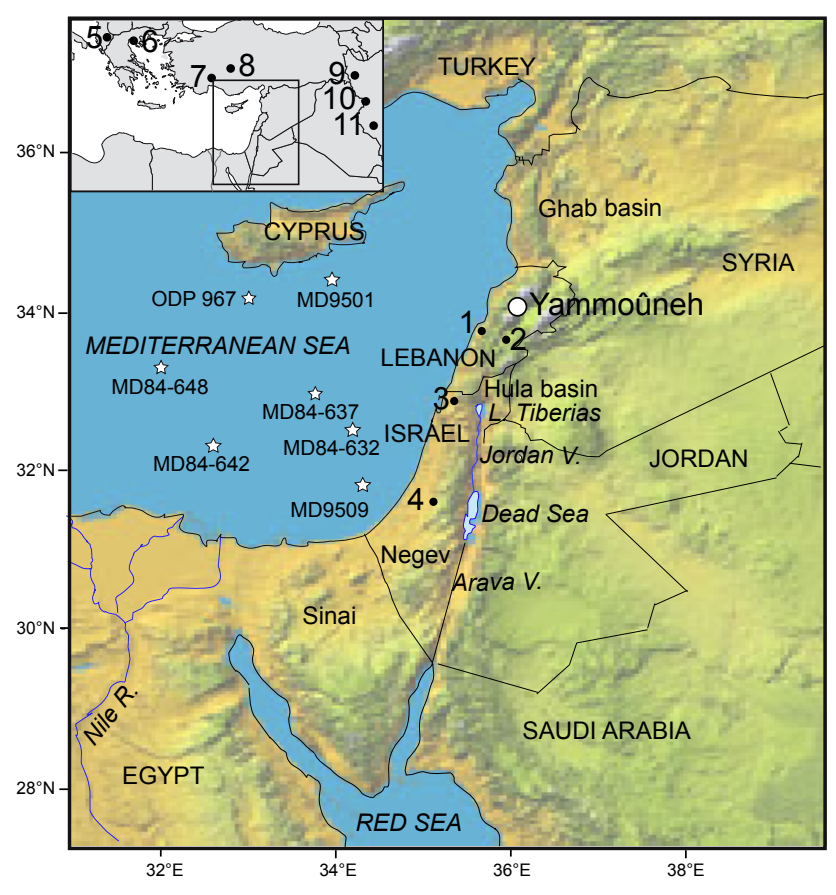

Fig. 1. The Levant in the eastern Mediterranean region. Location of the Yammoûneh basin and of sites cited in the text. For terrestrial records, 1: Jeita Cave; 2: Aammish marsh; 3: Peqi' in Cave; 4: Soreq Cave; 5: Lake Ohrid; 6: Tenaghi Philippon; 7: Lake Gölhisar; 8: Lake Konya; 9: Lake Urmia; 10: Lake Zeribar; 11: Lake Mirabad.

have suggested dry-cool glacial and wet-warm interglacial conditions (Bar-Matthews et al., 2003). This clearly highlights contrasted or controversial pictures of the hydrological evolution of the Levantine region. Furthermore, the complex regional physiographic pattern, the scarcity of records extending beyond the Last Glacial Maximum (LGM) in northern Levant and the differences in data interpretation might explain part of the heterogeneity of the climate signals. It is also noteworthy to underline that most of the available records are based on a single type of proxy knowing that none of the before cited proxy/archive are univocal when interpreted as a unique climate parameter. Crucial questions remain on the relative contributions of temperature, precipitation, evaporation and seasonal changes to the response of environmental indicators and of hydro-, eco-systems to climate changes. Multi-proxy analyses of sedimentary profiles may help disentangle the impacts of these climatic variables.

This present paper focuses on the interpretation of a multiapproach study, integrating sedimentological, paleobotanical and isotopic data, of a long sedimentary sequence $(250 \mathrm{ka})$. This sub-continuous lacustrine/palustrine sequence comes from a small, intra-mountainous karstic basin lying in the poorly known northern Levant (Yammoûneh, Lebanon). Results already published on the sedimentary profile are briefly summarized (chronology and sedimentary processes for the past $250 \mathrm{ka}$; carbonate oxygen isotopes for the past $21 \mathrm{ka}$; 

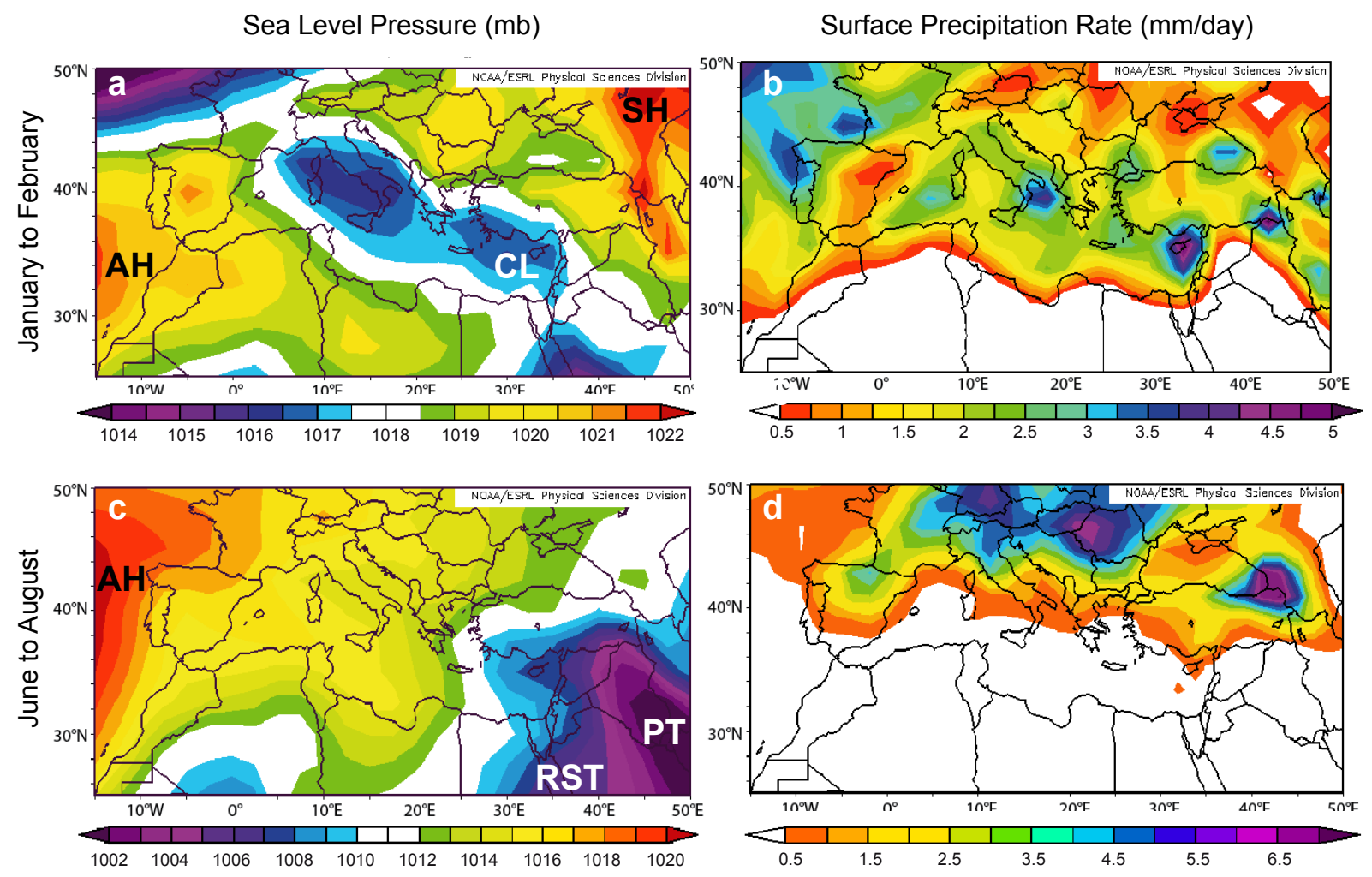

Fig. 2. Sea level pressure and surface precipitation rate in the Mediterranean region in winter - January-February: (a), (b) - and summer - June-August: (c), (d) - averaged from 1968 to 1996. Source: NCEP/NCAR Reanalysis. NCAA/ESLP Physical Sciences Division (http://www.cdc.noaa.gov/Composites/Day/). AH: Azores High; SH: Siberian High; CL: Cyprus Low; RST: Red Sea Trough; PT: Persian Trough.

Develle et al., 2010, 2011). Attention is paid here to new data: pollen-inferred paleovegetation and biogenic carbonate $\delta^{18} \mathrm{O}$ data of the whole sequence. Our main aim is to yield a comprehensive view of the long-term environmental fluctuations in the Yammoûneh basin over the two last glacialinterglacial cycles by integrating the different proxies. Our record is then replaced in its regional context. The paper is underlaid by the following questions:

1. What are the relationships between individual proxies?

2. What are the main environmental characteristics of the Yammoûneh basin during full glacial and interglacial peaks?

3. How does this record from northern Lebanon compare with other long-term records from central and southern Levant and from northeastern Mediterranean?

\section{Modern setting}

\subsection{Main physiogeographic and climate features of the Levant region}

The steep topography of the Levant is related to the active Levant Fault System (Le Pichon and Gaulier, 1988) that runs from the NW tip of the Red Sea to SE Turkey through the Arava Valley, the Dead Sea-Jordan Valley-Lake Tiberias-Hula basins to the Ghab basin in Syria (Fig. 1). East of narrow coastal plains, the SSW-NNE mountain ranges culminate at $3083 \mathrm{~m}$ a.s.l. in Mount Lebanon at only $20-25 \mathrm{~km}$ from the sea shore, while the Dead Sea basin represents the lowest spot of the Earth. Orography and distance from the seashore strongly modulate the local rainfall patterns.

The Levant experiences a Mediterranean climate with wet cool winter and warm dry summer, primarily controlled by the Mediterranean cyclonic system intimately tied to the North Alantic system. Winter precipitation is generated by the cyclonic activity over the Sea (Sharon and Kutiel, 1986), when the Siberian anticyclone is reinforced over SW Asia and the Azores High extends over North Africa and Spain (Fig. 2a and b). The Mediterranean cyclogenesis is influenced by the surrounding regions and possibly by long 
distance teleconnections, e.g., the North Atlantic Oscillation (NAO) (Ziv et al., 2006, 2010; Dayan et al., 2008; Raible et al., 2010). Cyclones, either generated in the Mediterranean basin or penetrating from the North Atlantic, are steered by the mid-latitude westerlies and tend to propagate eastward along the northern coast of the Mediterranean until reaching the Levant region. When propagating over the relatively warm seawater, air masses become saturated by moisture. In the EMS, polar intrusions create a deep upper-level trough accompanied by low-level cyclogenesis. The strength and position of cyclones formed or reactivated in the EMS (the Cyprus Lows, Fig. 2a) largely control the winter rainfall temporal and spatial variability in the Levant (Enzel et al., 2003; Ziv et al., 2006). In summer (Fig. 2c and d), when the Siberian anticyclone is attenuated and the Azores anticyclone and the mid-latitude westerly belt are shifted northward, the Levantine region is warm and dry. The summer low-pressure systems developed southward and eastward (the Red Sea Trough and the Persian Trough) are generally hot and dry (Kahana et al., 2002).

Several mechanisms indirectly link the Levant to subtropical and tropical climates. Very dry summer conditions over the eastern Mediterranean region and northeastern Sahara are partly due to the subsidence of easterly airflows linked to the Indian monsoon activity (Rodwell and Hopkins, 1996; Ziv et al., 2004). Most of the occasional rainfall events occurring in the Negev desert during spring and autumn are in conjunction with an active Red Sea Trough (Kahana et al., 2002). Heavy dust storms of North African origin are frequent from December to April. Saharan dust influx to the region has often been attributed to the thermal lows of the Sharav cyclones formed over Libya and Egypt (Alpert and Ziv, 1989) and the Red Sea Trough, but the cold Cyprus Lows also play a major role in attracting Saharan dust plumes (Dayan et al., 2008). The Nile River discharge, which depends on tropical rainfall in East Africa, affects the EMS hydrothermal dynamics (Rossignol-Strick and Paterne, 1999) and, thus, sea-land interactions.

\subsection{The Yammoûneh basin in Lebanon}

The Yammoûneh basin $\left(34.06^{\circ} \mathrm{N}-34.09^{\circ} \mathrm{N}, \quad 36.0^{\circ} \mathrm{E}-\right.$ $36.03^{\circ} \mathrm{E}, 1360 \mathrm{~m}$ a.s.1.), $6 \mathrm{~km}$ long, $2 \mathrm{~km}$ wide, lies at approximately $37 \mathrm{~km}$ from the seashore on the eastern flank of Mount Lebanon (Fig. 3). It was occupied in its southern part by a seasonal lake from at least Roman times to the 1930s when it was drained for irrigation of the Bakka plain. It is today entirely cultivated. No paleo-shoreline was observed, suggesting that the paleolake never reached high levels during a period long enough to leave geomorphic evidence. The basin is a SSW-NNE depression of tectonic origin along the Yammoûneh Fault, a segment of the Levant Fault System. It was downfaulted through thick sub-tabular sequence of intensively karstified Cenomanian dolomitic limestones (Dubertret, 1975; Hakim, 1985). The strike-slip
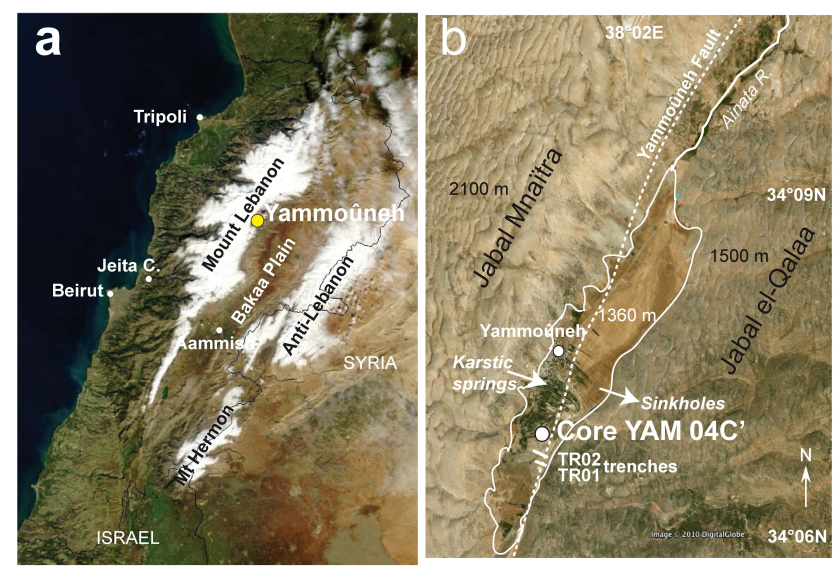

Fig. 3. The Yammoûneh basin in Lebanon. (a) Satellite view of Lebanon in winter (January 2003), main morphological structures. (b) The Yammoûneh basin with location of the sedimentary profiles. Dashed line: surface trace of the Yammoûneh Fault. Arrows schematize the groundwater circulation, from the Mnaïtra Plateau which provides the main water inflow to the basin via karstic springs emerging along the western edge of the basin, and infiltration along the eastern edge.

Yammoûneh Fault is active (slip rate: $3.8-6.4 \mathrm{~mm} \mathrm{yr}^{-1}$ ), but vertical movements likely remained negligible during the Late Quaternary (Daëron et al., 2004, 2007; A. R. Elias, personal communication, 2009). The Yammoûneh basin is limited by the high Mnaïtra plateau (2100 ma.s.l.) that abruptly rises westward, and by the gently sloping hills (Jabal el-Qalaa, $1500 \mathrm{~m}$ a.s.1.) which separates the basin and the large Bakka plain syncline to the East.

In Lebanon (Service Météorologique du Liban, 1977), Mean Annual Precipitation (MAP) ranges from 700$1000 \mathrm{~mm}$ along the coast, $>1400 \mathrm{~mm}$ in Mount Lebanon, to $400 \mathrm{~mm}$ in the Bakka plain and $<200 \mathrm{~mm}$ in the NE. Above $2000 \mathrm{~m}$ a.s.l., precipitation is essentially niveous. At Yammoûneh, MAP reaches $900-1000 \mathrm{~mm}$, as snow falls over about 30 days $\mathrm{yr}^{-1}$. The wet-cold season (NovemberMarch) culminates in January, while precipitation is almost nil from June to August. Continentality is marked by large diurnal and seasonal variations in temperature and air humidity. Mean Annual Temperature (MAT) is about $15^{\circ} \mathrm{C}$ but freezing occurs over 3 months $\mathrm{yr}^{-1}$ and temperature maximum largely exceeds $30^{\circ} \mathrm{C}$ during the warmest month (July).

The strong rainfall and temperature gradients in Lebanon result in vegetation zones ranging from forest and woodland to open steppe (Abi-Saleh and Safi, 1988). The climatic characteristics and typical plant taxa of vegetation zones are summarized in Table 1. The western slopes of Mount Lebanon present a transition, with increasing elevation, from successive Mediterranean belts with very warm to more temperate climate, a mountain and a subalpine belts characterised by trees of cool-wet conifer forests up to the treeline. Due to the gradual change to continental Mediterranean 
Table 1. Distribution of the modern vegetation belts in the Yammoûneh area as a function of location, altitude, mean annual precipitation (MAP) and mean annual temperature (MAT). After Abi-Saleh and Safi (1988).

\begin{tabular}{|c|c|c|c|c|c|}
\hline & $\begin{array}{l}\text { Altitude } \\
\text { (m a.s.l.) }\end{array}$ & $\begin{array}{l}\text { MAP } \\
\left(\mathrm{mm} \mathrm{yr}^{-1}\right)\end{array}$ & $\begin{array}{l}\text { MAT } \\
\left(T^{\circ} \mathrm{C}\right)\end{array}$ & Characteristic plant taxa & \\
\hline \multicolumn{6}{|c|}{ Western flank of Mt Lebanon } \\
\hline $\begin{array}{l}\text { Lower Mediterranean belt } \\
\text { Middle Mediterranean belt } \\
\text { Upper Mediterranean belt }\end{array}$ & $\begin{array}{l}0-500 \\
500-1000 \\
1000-1500\end{array}$ & $\begin{array}{l}>600 \\
800-1000 \\
>900-1000\end{array}$ & $\begin{array}{l}20 \\
16-18 \\
15-16\end{array}$ & $\begin{array}{l}\text { Ceratonia silica, Pistacia lentiscus, Myrtus communis } \\
\text { Evergreen oak Quercus calliprinos, Pinus brutia, P. pinea } \\
\text { Lower part: } Q . \text { calliprinos } \\
\text { Upwards: deciduous oaks: } \\
Q . \text { infectoria, } Q . \text { cerris }\end{array}$ & 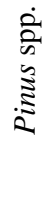 \\
\hline $\begin{array}{l}\text { Mountain belt } \\
\text { Subalpine belt }\end{array}$ & $\begin{array}{l}1500-2000 \\
>2000\end{array}$ & $\begin{array}{l}>1000 \\
>1200\end{array}$ & $\begin{array}{l}5-15 \\
0-5\end{array}$ & $\begin{array}{l}\text { Cedrus libani, Abies cilicica } \\
\text { Juniperus excelsa up to the tree line }\end{array}$ & \\
\hline \multicolumn{6}{|c|}{ Eastern flank of Mt Lebanon } \\
\hline & $\begin{array}{l}900-1800 \\
>1800\end{array}$ & $\begin{array}{l}600-800 \\
>800\end{array}$ & $\begin{array}{l}16-18 \\
<16\end{array}$ & $\begin{array}{l}Q . \text { calliprinos, } Q . \text { infectoria } \\
\text { Juniperus excelsa }\end{array}$ & \\
\hline \multicolumn{6}{|c|}{ Bakka plain } \\
\hline & $900-1100$ & $200-600$ & 15 & $\begin{array}{l}\text { Abundant steppe elements } \\
\text { Hammada eigii Artemisia herba alba Salsola villosa } \\
\text { Noaea mucronata }\end{array}$ & \\
\hline
\end{tabular}

and sub-desertic conditions, the eastern slopes receive less rainfall than corresponding altitudes in west Lebanon. Only Mediterranean oaks, and junipers at high elevation, are present. The much drier Bakka plain is open to influx of steppe elements from the adjacent Irano-Turanian territory. Human impact has considerably deteriorated and modified the natural ecosystems since millenia.

Hydrologically, the Yammoûneh basin primarily depends on precipitation over the western highlands. Direct precipitation on the paleolake surface $\left(<1.2 \times 10^{6} \mathrm{~m}^{3} \mathrm{yr}^{-1}\right)$ and on the small surface watershed $\left(\sim 105 \mathrm{~km}^{2}\right.$; Develle et al., 2011) is negligible compared to the important water inflow brought by permanent karstic springs $\left(35-70 \times 10^{6} \mathrm{~m}^{3} \mathrm{yr}^{-1}\right.$; Besançon, 1968; Hakim, 1985). Beneath the Mnaïtra plateau, subterranean karstic networks collect snowmelt water feeding a dozen springs along the western edge of the basin. The cool karstic spring water exhibits an isotopic composition (mean: $\delta^{18} \mathrm{O}=\sim-8.9 \%$ o $\delta \mathrm{D}=\sim-50.8 \%$ ) very close to that of winter rainfall ( $\sim 90 \%$ of MAP) in the watershed (Develle et al., 2010), without significant impact of evaporation or sublimation before infiltration (Aouad et al., 2004). Studies of nearby karstic aquifer systems show that groundwater residence time is negligible on the geological time-scale (from 1 season to 2-3 years; Aouad et al., 2005; El Hakim, 2005). In the basin floor, sinuous channels drain spring and runoff water from the west into karstic sinkholes along the eastern border. The karstified, intensively fissured and faulted substrate, is highly permeable. Hence, the basin is hydrologically open with rapid throughflow. Water residence time and relative evaporation losses may have, however, increased when a permanent lake occupied the basin.

\section{Stratigraphy, chronology and sedimentary processes}

Descriptions of stratigraphical units, analytical methods applied for chronology and sedimentology, and discussions on result interpretations are detailed in Develle (2010) and Develle et al. (2010, 2011). Main results are summarized below.

\subsection{Stratigraphy}

The upper $36 \mathrm{~m}$ of the sediment core (YAM-04C', $73 \mathrm{~m}$ ) collected in 2004 from the central part of the Yammoûneh paleolake (Fig. 3) has revealed a sub-continuous accumulation of lacustrine-palustrine sediments. A very simplified stratigraphic log and pictures of some core sections illustrate the variety of lithofacies (Fig. 4). As the uppermost Unit I is truncated in the core, some data were derived from nearby trenches (TR01, TR02, Fig. 3) which contain the whole Holocene period.

The profile shows two main types of sediments, although transitions between stratigraphic units are often gradual:

1. Pale intervals, a few metres thick, dominated by carbonates. They consist of whitish powdery silt or very fine sand (Units I, VI and IX; Fig. 4e) rich in calcified remains of aquatic organisms (gastropods, ostracods, 


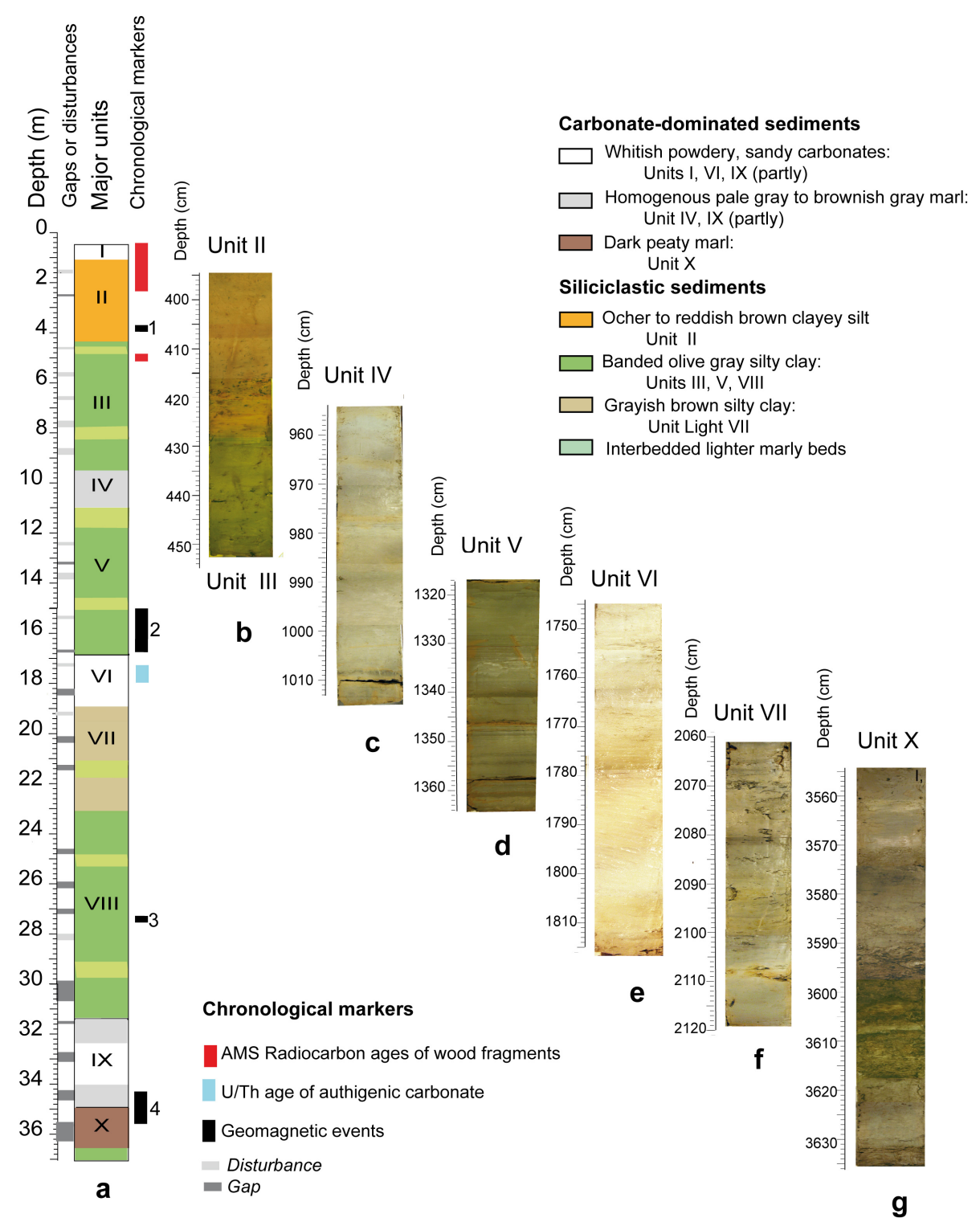

Fig. 4. Stratigraphy and lithofacies of the upper $36 \mathrm{~m}$ of core Yam $04 \mathrm{C}^{\prime}$. (a) Simplified stratigraphic log. Position of gaps in core recovery and of sediment disturbances on the left; position of chronological markers on the right. (b) to (g) Pictures of some core sections illustrating the facies diversity. (b) Transition from reddish, oxidized silt of Unit II to olive gray silty clay of Unit III. (c) Pale greenish marl. (d) Typical banded greenish marl. (e) Typical interglacial calcitic powdery deposits. (f) Brownish, coarsely banded silty clay. (g) Peaty marl of Unit X.

charophytes, fish otoliths ...), or of light gray to light brown marl (Unit IV and part of Unit IX; Fig. 4c).

2. Thick accumulations of intensively coloured silty clay. This siliciclastic material is almost devoid of shells (besides ostracods). The ocher to reddish brown Unit II (Fig. 4b) shows numerous strongly oxidized, indurated layers and beds of coarse limestone gravels and concretions. Units III, V, VII and VIII consist of plastic olive gray (Fig. 4d) or grayish brown silty clay (Fig. 4f) often organised in bands $2-20 \mathrm{~cm}$ thick. Several layers, 3-8 cm thick, suggest paleosoils; a few centimetric intervals are laminated; lighter marly intervals are interbedded in these units.

The lowest carbonate-rich Unit X (Fig. 4g) differs from others by its very dark brownish to black colour and its peaty feature, rich in aquatic plant fragments, beds of fish otoliths and well-preserved mollusc shells. Below $3650 \mathrm{~cm}$, it overlays greenish clays resembling Units III or VIII.

All encountered remains of aquatic organisms are typical of fresh, shallow or even ephemeral waterbodies.

Analyses performed on the core for environmental reconstruction are listed in Table 2. 
Table 2. Performed analyses on the upper $36 \mathrm{~m}$ of core YAM04-C'. Variables included in the PCAPM analysis (Fig. 8) are numbered in column 2.

\begin{tabular}{|c|c|c|c|c|c|}
\hline $\begin{array}{l}\text { Observations and } \\
\text { Analyses }\end{array}$ & $\begin{array}{r}\text { Variables } \\
\text { included } \\
\text { in PCA }\end{array}$ & Variable & & $\begin{array}{r}\mathrm{Nb} \text { of } \\
\text { analysed } \\
\text { samples }\end{array}$ & \\
\hline \multirow[t]{6}{*}{ Main lithofacies types } & 1 & Whitish powdery, sandy carbonate & 1 & continous & \\
\hline & & Pale gray to pale brown marl & 2 & continous & \\
\hline & & Yellowish brown to reddish brown silt & 3 & continous & \\
\hline & & Olive gray silty clay & 4 & continous & \\
\hline & & Brownish gray silty clay & 5 & continous & \\
\hline & & Dark brown, peaty or paleosoil-like levels & 6 & continous & \\
\hline \multirow[t]{13}{*}{ Sediment composition } & 2 & XRD mineralgy (\% weight dry sediment) & Calcite (+ Aragonite: $0-3 \%$ ) & 160 & $\cong$ \\
\hline & 3 & & Quartz & 160 & $\bar{\Xi}$ \\
\hline & 4 & & K-Feldspaths + Plagioclases & 160 & $\bar{z}$ \\
\hline & 5 & & Dolomite & 160 & $\stackrel{\mathscr{g}}{\Xi}$ \\
\hline & 6 & & Clay minerals & 160 & 政 \\
\hline & 7 & TOM (\% weight dry sediment) & & 160 & \\
\hline & 8 & Total magnetic susceptibility $\left(10^{-5} \mathrm{SI}\right)$ & & 2417 & \\
\hline & 9 & XRF Element relative content & $\mathrm{Ca}$ & 2109 & \\
\hline & 10 & & $\mathrm{Si}$ & 2109 & \\
\hline & 11 & & $\mathrm{Al}$ & 2109 & \\
\hline & 12 & & $\mathrm{Fe}$ & 2109 & \\
\hline & 13 & & $\mathrm{Ti}$ & 2109 & \\
\hline & 14 & & $\mathrm{~K}$ & 2109 & \\
\hline \multirow[t]{6}{*}{ Pollen analysis } & 15 & Steppic-desertic landscape & Artemisia + Chenopodiacea + Cichoroideae & 225 & \\
\hline & 16 & Middle Mediterranean zone & Pinus + evergreen Quercus & 225 & \\
\hline & 17 & Upper Mediterranean zone & Deciduous Quercus & 225 & \\
\hline & 18 & Montane belt & Cedrus + Abies & 225 & \\
\hline & 19 & Subalpine zone & Juniperus & 225 & \\
\hline & 20 & Aquatic + Hydrophilous ( $\%$ total pollen) & $\begin{array}{l}\text { Myrioplyllus, Potamogeton, Typha, } \\
\text { Cyperaceae, Ranunculus }\end{array}$ & 225 & \\
\hline Carbonate oxygen isotope & 21 & $\delta_{\mathrm{c}}$ derived from ostracod $\delta^{18} \mathrm{O}$ values & & 190 & \\
\hline \multirow[t]{2}{*}{ Microscopic observations } & & Smear slides & & 250 & \\
\hline & & Scanning electron microscope & & 52 & Same \\
\hline Grain size analysis & & & & 52 & samples \\
\hline
\end{tabular}

\subsection{Chronological framework}

The age model of core YAM-04C' was based on the combination of radiometric dating and magnetic chronostratigraphy. The position of dated levels along the profile is showed in Fig. 4a.

The top of the sequence was ${ }^{14} \mathrm{C}$-dated by Accelerator Mass Spectrometry (AMS) on partly carbonized wood fragments (11 levels from $0-21 \mathrm{ka} ; 0-250 \mathrm{~cm}$ ). A ${ }^{14} \mathrm{C}$ age at $535 \mathrm{~cm}(47 \pm 4 \mathrm{ka})$ should be regarded with caution as it reaches the limit of the ${ }^{14} \mathrm{C}$ method applicability. The ${ }^{14} \mathrm{C}$ ages were calibrated using IntCal 09 (Reimer et al., 2009). One level of almost pure authigenic calcite has provided a reliable U/Th age of $124 \pm 17 \mathrm{ka}$ at $1770 \mathrm{~cm}$. Four geomagnetic events (1 to 4; Fig. 4a) were identified, based on changes in inclination and relative paleointensity of the Earth magnetic field. The very well identified Event $2(1590-$ $1660 \mathrm{~cm})$ is the Blake event $(\sim 114-120 \mathrm{ka})$. Events 1 and 3 likely represent the Laschamp ( $41 \pm 2 \mathrm{ka}, 340-370 \mathrm{~cm}$, peaking at $361 \mathrm{~cm})$ and the Iceland Basin event $(\sim 190-194 \mathrm{ka}$;
$2735 \mathrm{~cm})$, respectively. Event $4(3420-3490 \mathrm{~cm})$ coincides either with the Pringle Falls event $(\sim 211 \mathrm{ka})$ or the Mamaku event $(230 \pm 12 \mathrm{ka})$. An approximate age of 230 $(+12 /-20) \mathrm{ka}$ was assigned at $3460 \mathrm{~cm}$.

The age-depth relationships were estimated by linear interpolation between the above-mentioned age control points, and Units were tentatively related to the stacked and orbitally-tuned Marine Isotope Stages (MIS; Martinson et al., 1987). We are aware that our age model only provides an approximate time scale, due to the low number of dated points and their age uncertainty, changes in sedimentation rate and possible sedimentation hiatuses. Nevertheless, ${ }^{14} \mathrm{C}$ ages clearly show that Unit I is of Holocene age (MIS 1). According to the U/Th date and the depth position of the geomagnetic Blake event, Unit VI is assigned with confidence to the last Interglacial peak (MIS 5.5). If the age of geomagnetic event 4 is correct, Unit IX represents MIS 7, a hypothesis supported by its lithofacies analogies with Units I and VI (Fig. 4a). 


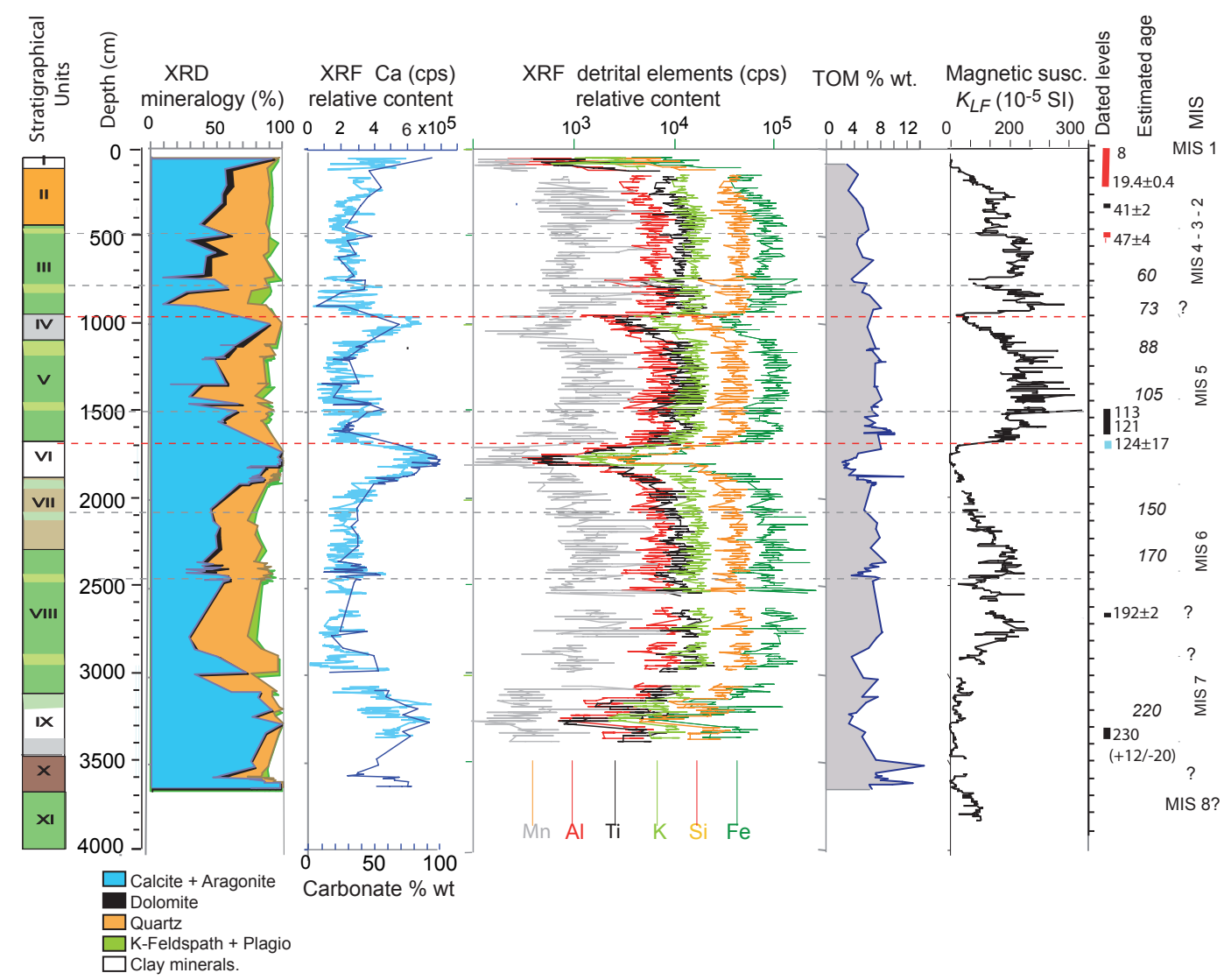

Fig. 5. Sedimentological data. Main proxies versus depth along the stratigraphical profile, after Develle et al. (2011). On the right, chronological information: position and measured ages of the chronological markers, estimated ages of major sedimentation changes (in italic, interpolated ages), and hypothesized relationships with Marine oxygen Isotope Stages (MISs; Martinson et al., 1987). Horizontal dashed lines: major (red) and second order (grey) sedimentation changes.

\subsection{Sedimentary processes}

Major sedimentary results are illustrated in Fig. 5.

Sedimentation has been primarily controlled by: (i) in situ lacustrine carbonate production, (ii) erosion of the surface watershed, and (iii) eolian inputs.

The whitish Units I, VI and IX coincide with interglacial periods (MIS 7, MIS 5.5, MIS 1). They consist mainly of calcite precipitated into the waterbody (authigenic rhomboedric crystals and biogenic fragments). Lacustrine calcite production was enhanced by high temperature and evaporation, strong biological activity in the lake, and high $\mathrm{Ca}^{2+}$ inputs suggesting heavy karstic spring discharge and active circulation in the Mnaiitra karstic system. Low magnetic susceptibility values and relatively low contents of $\mathrm{Fe}, \mathrm{Ti}$ and $\mathrm{K}$ and Total Organic Matter (TOM) were attributed to reduced local erosion and dilution of detrital particles by authigenic carbonates. The quasi-absence of runoff-derived material and high carbonate content may suggest very low rainfall. However, the synchrony of carbonate peaks with the abundance of lacustrine organisms and with the development of arboreal vegetation (see Sect. 4.1) reducing erosion processes rather reflects high water availability in both the karstic recharge zone and the paleolake surroundings.

Coloured clayey silts (Units III, V, VII, VIII) are mainly composed of eolian and local terrigenous material. Lithofacies which include paleosoils and the scarcity of aquatic organisms (mainly ostracod taxa surviving ephemeral conditions) reflect shallow, unstable palustral environments. Quartz, K-feldspars and plagioclases, almost absent in the local bedrock, are obviously allochtonous and windblown from remote sources. Quartz (up to $60 \%$ ) largely dominate the non-carbonated fraction, reflecting a high contribution of eolian dust to sedimentation, either from direct falls or reworked from the basin slopes. Calcite, present throughout, generally occurs in aggregates resembling those found in watershed soils or as limestone gravels, indicating its detrital origin. Dolomite is also probably eroded from the bedrock. Clay minerals (smectite mainly, kaolinite, traces of illite) are attributed to weathering and runoff in the basin, implying at least occasional heavy floods. Elements other than Ca prevail and are supported by minerals of detrital origin responsible for high magnetic susceptibility values. 


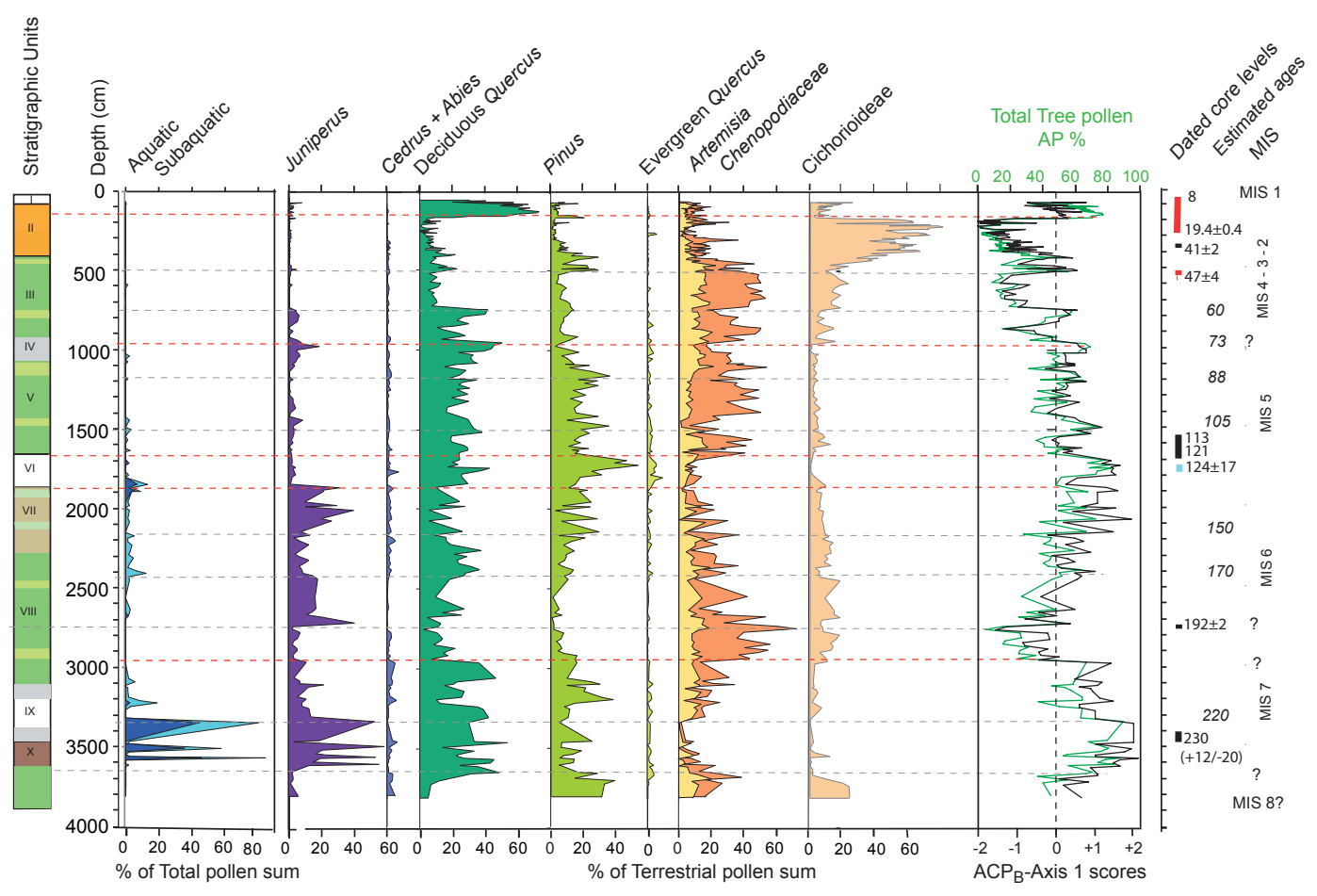

Fig. 6. Palynological data. Relative frequencies of selected pollen taxa versus depth along the stratigraphical profile, total tree pollen percentages $(\mathrm{AP} \%)$ and $\mathrm{ACP}_{\mathrm{B}}$-Axis 1 scores showing the alternance of forested and steppic landscapes. Chronological information as for Fig. 5. Horizontal dashed lines: major (red) and second order (grey) vegetation changes.

Marls (Unit IV and IX) and pale marly layers interbedded in silty clay are intermediate between these two typical sediment types. The peaty marl of Unit X, rich in TOM and biogenic rests, indicates the occurrence of a productive lake at the core site.

\section{New data from the Yammoûneh sequence}

\subsection{The pollen record}

Most of the Yammoûneh sequence contains pollen grains, although its top $(<8.3 \mathrm{ka})$ is sterile possibly due to oxidation after the lake drainage. Vegetation patterns inferred from the pollen record were based on 225 samples prepared for pollen analysis using standard palynological procedures. An average of 465 pollen grains was counted in each sample. A total of 69 pollen taxa were identified, using reference collections and Reille's (1992) pollen atlas.

Pollen results are given as a percentage diagram of selected taxa (Fig. 6). Aquatic (Myriophyllum mainly) and marsh (Cyperaceae dominant) plant pollen, indicative of permanent lacustrine conditions or swamps around the core site, respectively, are expressed in percents of the total pollen sum. Both reach their highest percentages in the lower half of the core and then tend to disappear, suggesting drier local conditions above $1800 \mathrm{~cm}$.
Terrestrial pollen taxa are expressed in percents of a basic sum excluding pollen from aquatic and marsh plant pollen. See Table 1 for the modern distribution of major taxa. Main tree pollen include: (1) Juniperus and Cedrus-Abies representative of cool conifer forests from the subalpine and mountain belts, respectively. Note that Cedrus and Abies, which require high water availability, do not extend today east of Mount Lebanon; (2) deciduous Quercus, common in the temperate and warm-mixed forests of the upper Mediterranean belt;(3) Pinus, a rather ubiquitous taxa growing in all Mediterranean vegetation belts; (4) evergreen Quercus, a xerophytic Mediterranean tree which spreads in the lower Mediterranean belt and at moderate elevation east of Mount Lebanon; (5) Artemisia and Chenopodiaceae, the most significant herbaceous taxa which reflect the development of steppic landscapes; (6) Cichorioideae pollen, which can account for more than $50 \%$ of the terrestrial pollen above $400 \mathrm{~cm}$. Strong representation of this pollen type may result from taphonomic processes and poor preservation conditions (Bottema, 1975), i.e., large water table fluctuations and frequent emersions, as suggested by strongly oxidized and indurated layers in the sedimentary Unit II, indicating unstable but generally dry conditions. This pollen type is present is various amounts throughout the sequence and was not excluded from the pollen calculations. 
The total percentage of tree pollen (AP\%) provides a broad view of the alternance between forested and steppic landscapes, mainly reflecting changes from moist to drier conditions although very cold climate might have limited the tree growth. The few available regional modern pollen spectra prevent any application of a pollen-based transfer function to quantify changes in rainfall amount or in temperature. Terrestrial pollen data were converted into Plant Functional Types (PFTs) and a pollen-derived biomization of the PFTs was elaborated using the appropriate methods for Mediterranean regions (Tarasov et al., 1998). Five pollen-derived biomes (PdBs; scores not shown) were inferred from the Yammoûneh dataset: (1) cool conifer forest; (2) temperate deciduous forest; (3) warm mixed forest; (4) xerophytic woods/shrubs; (5) steppe. Hot and cool steppe biomes were not separated, because of the low representation of discriminating pollen taxa in the spectra. When affinity score differences between biomes are low, the use of the highest-scoring PdB alone may obscure significant vegetation changes. Therefore, a down-core ordination of samples taking into account major changes in all the PdB-scores was obtained by a principal component analysis $\left(\mathrm{PCA}_{\mathrm{B}}\right)$. The general pattern of the $\mathrm{PCA}_{\mathrm{B}}$ scores is not affected when excluding Asteraceae subfam. Cichorioideae from the basic sum. $\mathrm{PCA}_{\mathrm{B}}$-Axis 1 ( $77.98 \%$ of total inertia) is positively loaded by all forested biomes (PdBs 1 to 4; pollen taxa groups 1 to 4 ), and negatively by steppe (PdB-5, pollen taxa group 5). Intervals of highest $\mathrm{PCA}_{\mathrm{B}}$-Axis 1 correspond to periods of best development of arboreal vegetation, whereas its lowest values indicate the dominance of open vegetation types. $\mathrm{PCA}_{\mathrm{B}}$-Axis 1 closely resembles the $\mathrm{AP} \%$ curve, but highlights the development of tree elements below $1800 \mathrm{~cm}$.

Below $3670 \mathrm{~cm}$ ( $>240 \mathrm{ka}$ ), the dominance of steppe (PdB 5) punctuated by stands of pines may represent the MIS 8-MIS 7 transition. The interval 3670-3320 cm ( 240$220 \mathrm{ka}$ ?, early-mid MIS 7) has the highest $\mathrm{PCA}_{\mathrm{B}}$-Axis 1. PdB-1 dominated over the basin slopes, as showed by the highest Juniperus frequencies associated with Cedrus. Highest aquatic pollen frequencies indicate permanent lacustrine conditions, allowing the development of riparian deciduous oak groves (deciduous Quercus). This indicates high Precipitation $(P)$ and low Evaporation $(E)$ favoured by cool temperatures. From 3320 to $2970 \mathrm{~cm}$ (late MIS 7?) the increase in temperate Mediterranean trees and steppic taxa, responsible for intermediate $\mathrm{PCA}_{\mathrm{B}}$-Axis 1 values, reflects lower effective moisture partly explained by higher temperature as suggested by the falling representation of Juniperus.

The interval 2970-1870 cm, assigned to MIS 6 (although its base is $\sim 10 \mathrm{ka}$ too old in our age model), is first characterised by a strong dominance of steppe (PdB 5), and the almost disappearance of aquatic and palustral pollen. This suggests very dry conditions, although the opening of the landscape may partly result from the lowering of the upper tree line under glacial cooling. Above $2550 \mathrm{~cm}$ (180 ka?), a step-wise increase in $\mathrm{PCA}_{\mathrm{B}}$-Axis 1 depicts a progressive development of arboreal vegetation. High affinities to the PdB-1 loaded by Juniperus, Cedrus and Abies point to cool and wet conditions, as confirmed by small peaks of aquatic pollen.

MIS $5.5(\sim 1850-1680 \mathrm{~cm} ; \sim 130-120 \mathrm{ka})$ begins with a warming-induced abrupt fall of Juniperus and rise of both Quercus types. Then, temperate Quercus are rapidly replaced by a typical Mediterranean vegetation. $\mathrm{PCA}_{\mathrm{B}}-$ Axis 1 become very high when Pinus and evergreen Quercus reached their maximum percentages, and aquatic/palustral plant pollen disappeared. This vegetation does not lend support to aridity in the Yammoûneh basin, but for high seasonal contrasts. The largest population of evergreen Quercus suggests very dry summers, which increase the competitive advantage of Mediterranean sclerophyllous trees (Di Castri, 1981). After this last interglacial optimum, between 1680 and $960 \mathrm{~cm}$, a sharp increase in steppic elements is interrupted by two positive shifts in temperate/Mediterranean tree pollen frequencies, concomitant with small peaks of palustral plant pollen. These shifts, registered at 1520 $1480 \mathrm{~cm}(\sim 105 \mathrm{ka})$ and $1015-960 \mathrm{~cm}(\sim 80-73 \mathrm{ka})$, are assigned to MIS 5.3 and MIS 5.1, respectively.

From 960 to $220 \mathrm{~cm}$ ( 73-16 ka; MIS 4-3-2), the steppe development clearly depicts an overall drying trend from the beginning of MIS 4. This trend is interrupted by short, humid episodes revealed by positive shifts of $\mathrm{PCA}_{\mathrm{B}}$-Axis 1 at $820-750 \mathrm{~cm}$ and $500-410 \mathrm{~cm}(\sim 65-60$ and $45-40 \mathrm{ka}$, respectively, in our time scale). The lowest $\mathrm{PCA}_{\mathrm{B}}$-Axis 1 values of the whole record are reached at $240-220 \mathrm{~cm}(\sim 21-16 \mathrm{ka})$. This demonstrates that temperature and/or moisture conditions in the Yammouneh basin, together with very low $\mathrm{CO}_{2}$ atmospheric concentration, were not compatible with the development of an arboreal vegetation at the end of the LGM.

The last forested stage is recorded by a sharp increase of deciduous Quercus (PdB2) starting at $170 \mathrm{~cm}(13 \mathrm{ka})$, and culminated from 11 to $9 \mathrm{ka}$. It indicates the re-establishment of warmer/wetter conditions during the early Holocene.

Major points arising from the pollen study are the following:

- Arboreal vegetation dominates during interglacial optimums (early-mid MIS 7, MIS 5.5 and early MIS 1), reflecting relatively high effective moisture. Vegetation dynamics suggest very wet and cool conditions during MIS 7, strong thermal and hydrological seasonal contrasts during MIS 5.5, and wet temperate conditions during the early Holocene.

- The driest intervals appear at the end of the LGM and during early MIS 6.

- From $240 \mathrm{ka}$ onwards, each successive interglacial $\mathrm{PCA}_{\mathrm{B}}$-Axis 1 peak shows a decreasing amplitude. The same pattern holds true for glacial stages, showing a lower local moisture during the last glacial period than during MIS 6. The overall variation in the pollen record, 
including aquatic pollen, suggests a progressive decline in effective moisture as a result of the combined effect of temperature, precipitation and $p \mathrm{CO}_{2}$ fluctuations in the Yammoûneh basin.

\subsection{The carbonate oxygen isotope record}

The oxygen isotope composition of continental carbonates reflects complex interactions between several climatic variables and site-specific factors. In addition, in the case of biogenic carbonates, species-dependent factors (the so-called "vital effect" and auto-ecology) should be considered. We refer to Develle et al. (2010) and reference therein for analytical procedures, theoretical backgrounds and for the interpretation of the past $21 \mathrm{ka}$ isotope record. Authigenic carbonate $\delta^{18} \mathrm{O}$ values $\left(\delta_{\mathrm{c}}\right)$ are primarily controlled by water temperature and isotopic composition of the ambient water, here lake water $\left(\delta_{\mathrm{L}}\right)$. The $\delta_{\mathrm{L}}$ values are governed by the isotopic composition of the water inflow $\left(\delta_{\text {in }}\right)$ and of other terms of the lake water balance (inflow - [Evaporation + outflow]). The term $\delta_{\text {in }}$ depends on the precipitation $\delta^{18} \mathrm{O}$ values $\left(\delta_{\mathrm{P}}\right)$ and the P-E balance in the lake catchment. The $\delta_{\mathrm{P}}$ values are in turn controlled by the isotopic composition of the moisture source, here the EMS surface water $\left(\delta_{\mathrm{sw}}\right)$, stormtrack trajectories and the negative/positive relationships with local rainfall amount/ground-temperature. In central Levant, Frumkin et al. (1999), Bar-Matthews et al. (2003) and Kolodny et al. (2005) have showed that long-term $\delta^{18} \mathrm{O}$ fluctuations in inland carbonates are primarily driven by the glacial/interglacial variations in the isotopic composition of the EMS surface water. The rainfall amount probably represents the second order factor (Frumkin et al., 2011). BarMatthews et al. (2003) and Bar-Matthews and Ayalon (2004) took the temperature and rainfall amount into account to interpret low interglacial speleothem $\delta^{18} \mathrm{O}$ values.

The carbonate $\delta^{18} \mathrm{O}$ record from Yammoûneh was obtained from ostracod valves present and well preserved in most samples. Analyses were performed on the 4 most abundant taxa (Ilyocypris inermis, I. gibba, Candona neglecta in Unit I only, and Fabaeformiscandona balatonica only present below $1800 \mathrm{~cm}$; none of them occurs in sufficient number in all samples for analyses). Interspecific $\delta^{18} \mathrm{O}$ differences were determined, all values were normalized to the most widespread taxon (I. inermis) and corrected for the vital effect $(\sim 2.4 \%$ ) estimated for this species (Develle et al., 2010). This correction provides values coeval with that of authigenic calcite $\left(\delta_{\mathrm{c}}\right)$ which would have precipitated at equilibrium in the same ambient water. Along the entire profile, $\delta_{\mathrm{c}}$ values fluctuate by $5.1 \%$, between -12.6 and $-7.5 \%$ (Fig. 7a). The profile is characterised by $\delta_{\mathrm{c}}$ values generally lower before MIS 5.5, a reverse $\delta_{\mathrm{c}}$ trend between the penultimate and the last glacial periods, and very sharp $\delta_{\mathrm{c}}$ rises during interglacial peaks.

For the past $\sim 21 \mathrm{ka}$ (Develle et al., 2010), $\delta_{\mathrm{L}}$ was first estimated by correcting $\delta_{\mathrm{c}}$ for lake water temperature (assuming that the water temperature of the shallow Yammoûneh waterbody was in equilibrium with air/ground temperature), using the few available data on regional paleotemperatures. Second, isotopic composition of the moisture source $\left(\delta_{\mathrm{sw}}\right)$ was derived from planktonic foraminifera $(G$. ruber $) \delta^{18} \mathrm{O}$ records $\left(\delta_{\text {foram }}\right)$ in a Levantine core (MD84-632, Fig. 1; Essalami et al., 2007), corrected for surface water temperature using alkenone-based SST $\left(\mathrm{SST}_{\text {alk }}\right)$ records from the same core. Thirdly, the difference $\Delta^{18} \mathrm{O}=\delta_{\mathrm{L}}-\delta_{\mathrm{sw}}$ was calculated in order to discuss the impact of the "source effect" on the Yammoûneh isotopic signal, adopting an approach close to that of Almogi-Labin et al. (2009). Develle et al. (2010) concluded that both the "source effect", amplified by increase inland rainfall during the early Holocene, and the large glacialinterglacial temperature changes have been important drivers on $\delta^{18} \mathrm{O}$ fluctuations. Changes in storm-track trajectories may have also contributed to the signal.

The same approach is attempted here to interpret major glacial/interglacial $\delta_{\mathrm{c}}$ changes over the past $250 \mathrm{ka}$, but should be regarded with great caution because of large uncertainties on the timing and marine data (Fig. 7b-d) used to reconstruct $\delta_{\mathrm{sw}}$ and $\delta_{\mathrm{L}}$.

\subsubsection{Temperature effects}

In the Levant, inland quantitative paleotemperature estimates prior to the LGM are limited to punctual data inferred from isotope geochemistry of Soreq Cave speleothems between $140 \mathrm{ka}$ and present (McGarry al., 2004, Fig. 7b; Affeq et al.,

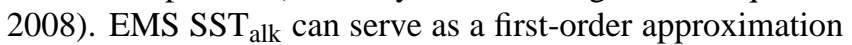
of land paleotemperatures for Levantine inland temperature (Bar-Matthews et al., 2003), at least at Soreq. SST $_{\text {alk }}$ records from the eastern EMS either do not extent over the last $250 \mathrm{ka}$ (Essalami et al., 2007; Castañeda et al., 2010) or are discontinuous (core ODP 967; Emeis et al., 2003). We used the $\mathrm{SST}_{\text {alk }}$ record of core MD40-71 (Figs. 1 and $7 \mathrm{~b}$ ) from the northwestern boundary of the Levantine basin (Emeis et al., 2003) as a rough regional indicator of temperature deviations relative to modern, $\Delta T$, at sea level $\left(\Delta T_{\text {sea level }}\right)$. These $\Delta T_{\text {sea level }}$ data were used to infer $\Delta T$ at Yammoûneh $\left(\Delta T_{\text {Yam }}\right)$ and to correct $\delta_{\mathrm{c}}$ for lake water temperature, applying the paleotemperature equation of Craig (1965) to calculate $\delta_{\mathrm{L}}$ (Fig. 7e). During Interglacials, we assume that the mean annual temperature difference between sea level and Yammoûneh was the same as today. During glacial periods, the thermal atmospheric lapse rate was steepened by at least $2{ }^{\circ} \mathrm{C} \mathrm{km}^{-1}$ during the LGM in the Mediterranean domain (Kuhlemann et al., 2008). An additional cooling of $2.5^{\circ} \mathrm{C}$ at Yammoûneh and $\geq 4^{\circ} \mathrm{C}$ in the aquifer recharge zone ( $>2000 \mathrm{~m}$ a.s.l.) would have induced an additional decrease of $\delta_{\mathrm{L}}$ of $\sim 0.7 \%$ (water temperature effect), but a larger decrease of $\delta_{\mathrm{P}}$ values of $\sim-1.4$ to at least $-2.3 \%$ due to the "ground-temperature effect" (estimated at $\sim 0.58 \% 0^{\circ} \mathrm{C}^{-1}$ in northern mid-latitudes; Rozanski et al., 1993) reducing the $\delta_{\mathrm{L}}-\delta_{\mathrm{P}}$ difference (Fig. 7e). Because most of the 


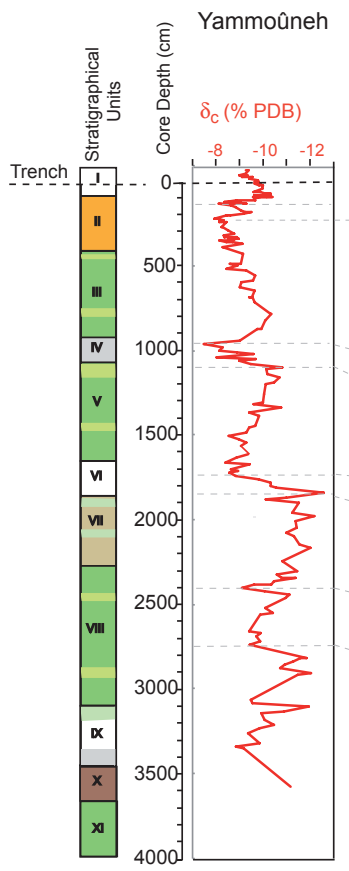

a

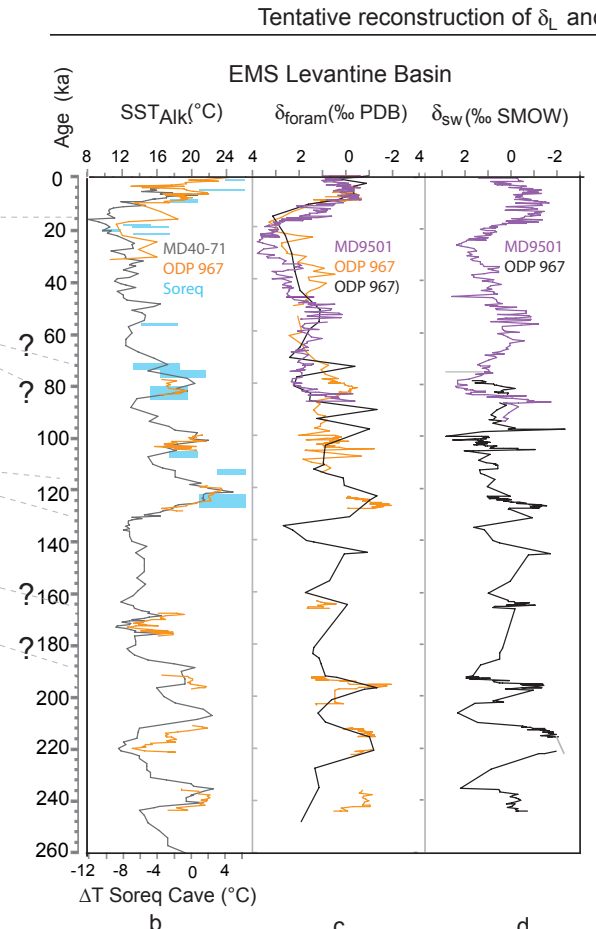

b

c

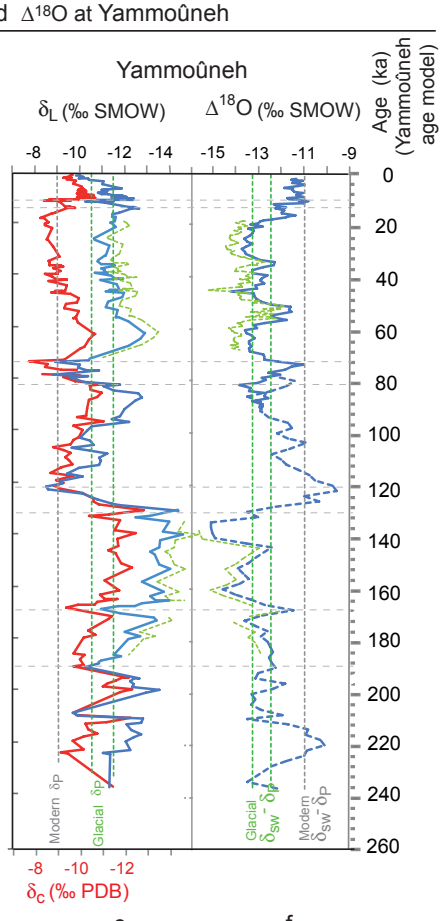

Fig. 7. Carbonate oxygen isotope record. Tentative reconstruction of $\delta_{\mathrm{L}}$ and $\Delta \delta^{18} \mathrm{O}=\delta_{\mathrm{Sw}}-\delta_{\mathrm{L}}$ using EMS marine data. (a) The Yammoûneh $\delta_{\mathrm{c}}$ profile versus depth (values above $0 \mathrm{~cm}$ of core depth come from trench TR02 which includes the entire Holocene period). (b) SST alk records from cores M40-71 and ODP 967 (Emeis et al., 2003), and inland temperature inferred from Soreq Cave speleothems (McGarry et al., 2004). (c) $\delta^{18} \mathrm{O}$ records of planktonic foraminifera ( $\left.\delta_{\text {foram }}\right)$ from cores MD9501 (Almogi-Labin et al., 2009) and ODP 967 (Kroon et al., 1998: black; Emeis et al., 2003: orange). (d) Isotopic composition of sea surface water $\left(\delta_{\text {sw }}\right)$ in the Levantine basin calculated from SSTs in core MD40-71 and $\delta_{\text {foram }}$ from cores MD9501 (0-86 ka) and ODP 967 (78-250 ka, combined Kroon et al., 1998 and Emeis et al., 2003 , data). (e) The Yammoûneh $\delta_{\mathrm{c}}$ profile and reconstructed $\delta_{\mathrm{L}}$ versus time (according to our age model). The blue $\delta_{\mathrm{L}}$ curve is based on inferred $\Delta T_{\text {sealevel }}$ on the modern mean annual temperature difference between sea level and Yammoûneh, the green one accounts for an additional altitudinal cooling during glacial periods. Vertical dashed lines: modern and inferred glacial $\delta_{\mathrm{P}}$ values. (f) Calculated $\Delta \delta^{18} \mathrm{O} . \mathrm{Colours}$ as for (e). Dashed and full blue curves are based on $\delta_{\mathrm{sw}}$ derived from cores ODP 967 and MD9501, respectively. Vertical dashed lines: $\delta_{\mathrm{sw}}-\delta_{\mathrm{P}}$ values inferred for modern and glacial times. See text for explanation.

precipitation was likely niveous (more depleted than liquid rainfall, Rozanski, 2005), $\delta_{\mathrm{P}}$ may have decreased even more.

In order to infer $\delta_{\mathrm{sw}}$, we used the high resolution time series of $\delta_{\text {foram }}$ from core MD-9501 (86 ka; Almogi-Labin et al., 2009) and the poorly-resolved record of ODP 967 from Kroon et al. (1998) complemented by detailed measurements around sapropel events (Emeis et al., 2003) (Figs. 1 and 7c). Although not recorded in SPECMAP (Imbrie et al., 1984), $\delta_{\text {foram }}$ fluctuations between $\sim 170$ and $\sim 150 \mathrm{ka}$ of the same amplitude as in ODP 967 were observed in cores MD84-648 and -637 (Fig. 1) closer to the Nile delta (Ducassou et al., 2007). By combining the $\Delta T_{\text {sealevel }}$ and the $\delta_{\text {foram }}$ values, we applied the same paleotemperature equation as for $\delta_{\mathrm{L}}$ to obtain an approximate record of $\delta_{\mathrm{sw}}$ for the northern Levantine basin (Fig. 7d).

\subsubsection{Source effect}

The "source effect" was extracted by calculating $\Delta \delta^{18} \mathrm{O}=\delta_{\mathrm{L}}-\delta_{\mathrm{sw}}$ (Fig. 8f). Large $\Delta \delta^{18} \mathrm{O}$ variations indicate that other factors than the "source effect" have acted on $\delta_{\mathrm{L}}$ and $\delta_{\mathrm{c}}$. During Interglacials, high $\Delta \delta^{18} \mathrm{O}$ values compared to the modern $\delta_{\mathrm{P}}-\delta_{\mathrm{sw}}$ difference $(\sim-11 \%$ o $)$ suggest enhanced inland rainfall around 220 and $125-120 \mathrm{ka}$ and less clearly around 105, 85-75 ka and 11-9 ka (Fig. 7f). These $\Delta \delta^{18} \mathrm{O}$ increases are associated with remarkable rises of $\delta_{\mathrm{c}}$ and $\delta_{\mathrm{L}}$, particularly clear at $\sim 126-120$ or $\sim 85-75 \mathrm{ka}$, which classically could suggest deficits in the lake water balance. Several hypotheses can be invoked to explain these apparent discrepancies. First, amplified seasonal thermal contrasts, as expected from orbital forcing, would have induced evaporative ${ }^{18} \mathrm{O}$-enrichment of $\delta_{\text {in }}$ and $\delta_{\mathrm{L}}$ during the warmer dry seasons. A longer water residence time in the paleolake could have also enhanced the evaporation effects when the waterbody was permanent. Second, 


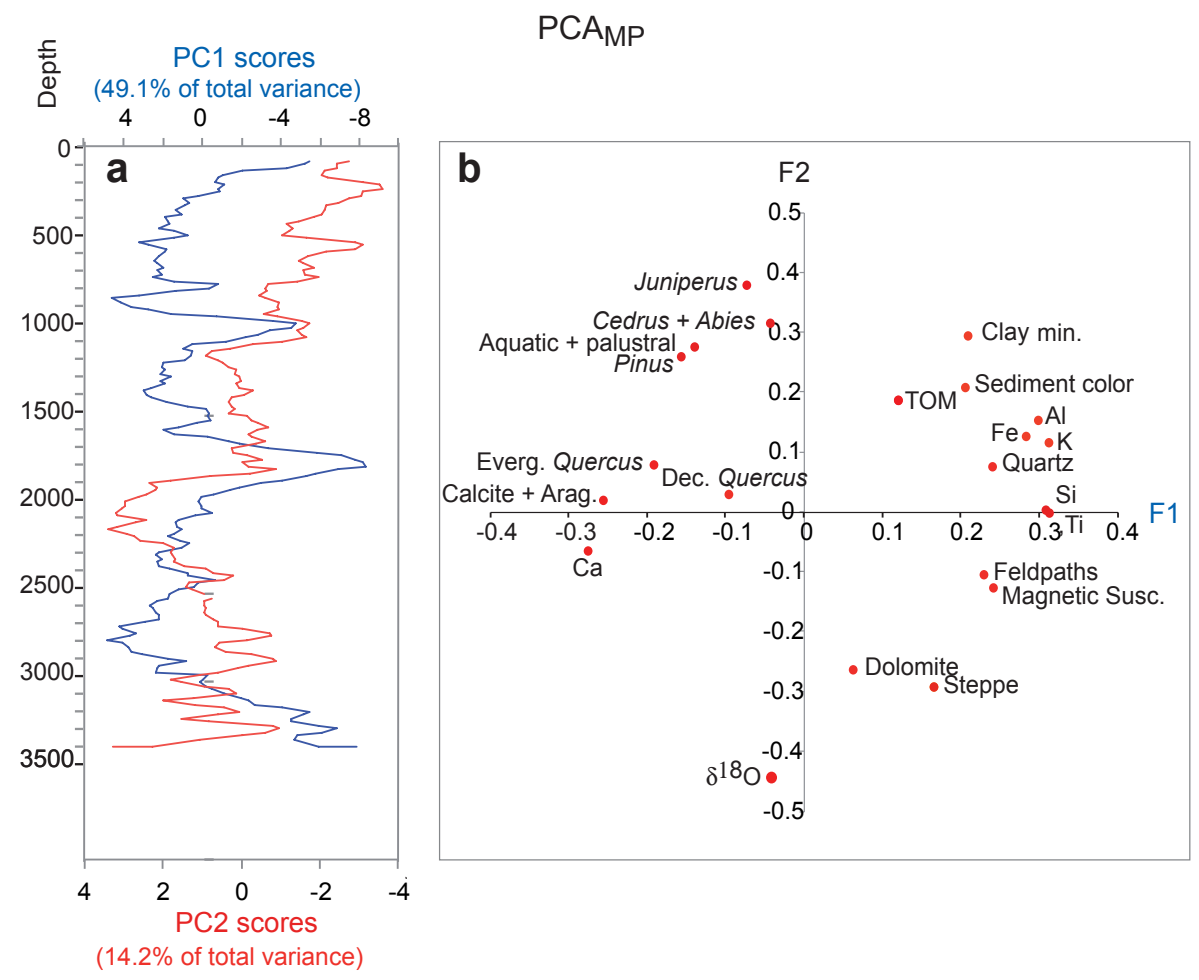

Fig. 8. Principal Component Analysis performed on 22 environmental variables (Tabl 2) in 166 core levels from core YAM04 C' (ACP ${ }_{M P}$ ). (a) Scores of the 2 first components (PC1 and PC2) versus depth. (b) Projection of environmental variables in the factorial plan F1-F2.

changes in rainfall seasonality might have affected $\delta_{\mathrm{P}}$ and, thus, $\delta_{\mathrm{L}}$ and $\Delta \delta^{18} \mathrm{O}$. At Yammoûneh, modern winter ${ }^{18} \mathrm{O}$ precipitation values are lower than spring and autumn values by $\sim 2.5 \%$ o (Develle et al., 2010). The transition to higher $\delta_{\mathrm{L}}$ and higher $\Delta \delta^{18} \mathrm{O}$ values could reflect a longer rainy season, increasing the relative contribution of spring and fall precipitation on the mean annual $\delta_{\mathrm{P}}$ values. Third, changes in air mass trajectories might have modified $\delta_{\mathrm{P}}$. Presently, at the rainfall event scale, the less ${ }^{18} \mathrm{O}$-depleted rains close to Beirut $\left(\delta_{\mathrm{P}}:-2\right.$ to $-4 \%$ ) are associated with air masses from the North (Aouad et al., 2004, 2005). Felis et al. (2004) have suggested increased advection over the near East of cold continental air from the North linked to a high NAO index in winter during MIS 5.5. Enhanced northerly winds might have increased $\delta_{\mathrm{P}}$. However, based on modern data, Vaks et al. (2010) suggested that a negative NAO index is linked to lower winter temperatures in Israel and leads to increased winter precipitation (and, thus, reduced winter $\delta_{\mathrm{P}}$ ).

During Glacials, $\Delta \delta^{18} \mathrm{O}$ was generally low, although sharp positive peaks around $\sim 170 \mathrm{ka}$ (in phase with a $\delta_{\mathrm{L}}$ increase), $\sim 145$ ka and during short MIS 4-3 intervals may reflect short wet pulses. Low $\delta_{\mathrm{c}}, \delta_{\mathrm{L}}$ and $\delta_{\mathrm{P}}$ values (Fig. 7e) suggest the dominance of ${ }^{18} \mathrm{O}$-depleted winter rains, low water and atmosphere temperatures and low evaporation rates. Freezing over most of the year have likely inhibited evaporative ${ }^{18} \mathrm{O}$ concentration. Changes in storm tracking may have contributed to the isotopic signal. Today, the most ${ }^{18} \mathrm{O}$-depleted rains reaching Lebanon $\left(\delta_{\mathrm{P}}:-6\right.$ to $-11 \%$ ) come directly from the west and have a long path over the sea (Aouad et al., 2004, 2005). Major storm-tracks funneled along the southern EMS coast due to ice extent in northern high latitudes, as proposed by Enzel et al. (2008), may have enhanced the $\delta \mathrm{P}$ and $\Delta \delta^{18} \mathrm{O}$ decreases.

\subsubsection{To sum-up}

Our approach suggests that the isotope balance of the Yammoûneh hydrosystem was initially controlled by the "source effect" $\left(\delta_{\mathrm{sw}}\right)$, but this effect was deeply modulated and modified by other factors associated with glacial/interglacial atmospheric patterns and the site-specific water balance. These factors include annual and seasonal changes in temperature and related evaporation rate, rainfall amount and rainfall isotopic composition.

\section{The multi-proxy Yammoûneh record}

\subsection{Relationships between individual proxies}

Information derived from individual indicators from a given sedimentary profile should be considered together and reconciled to gain a comprehensive picture of environmental conditions at a given time/core depth. 
Table 3. Significant simple linear correlation coefficients $(p<0.001)$ between environmental variables from Yammoûneh.

\begin{tabular}{|c|c|c|c|c|c|c|c|c|c|c|c|c|c|}
\hline & $\begin{array}{r}\mathrm{Ca} \\
\text { (rel. } \\
\text { cont) }\end{array}$ & $\begin{array}{r}\text { Calcite } \\
\text { (+ aragonite) }\end{array}$ & Quartz & $\begin{array}{l}\text { Kaolinite } \\
+ \text { smectite } \\
\text { + chlorite }\end{array}$ & $\begin{array}{r}\text { K-Fedspaths } \\
\text { + Plagio. }\end{array}$ & $\begin{array}{c}\text { Magnetic } \\
\text { Susceptinility }\end{array}$ & TOM & $\begin{array}{r}\mathrm{Al} \\
\text { (rel. } \\
\text { cont) }\end{array}$ & $\begin{array}{r}\mathrm{Si} \\
\text { (rel. } \\
\text { cont) }\end{array}$ & $\begin{array}{r}\mathrm{K} \\
\text { (rel. } \\
\text { cont) }\end{array}$ & $\begin{array}{r}\mathrm{Ti} \\
\text { (rel. } \\
\text { cont) }\end{array}$ & $\begin{array}{c}\mathrm{Fe} \\
\text { (rel. } \\
\text { cont) }\end{array}$ & $\begin{array}{r}\text { Deciduous } \\
\text { Quercus } \\
(\%)\end{array}$ \\
\hline Calcite (+ aragonite) (\%) & 0.791 & & & & & & & & & & & & \\
\hline Quartz (\%) & -0.756 & -0.970 & & & & & & & & & & & \\
\hline Kaolinite + smectite + chlorite $(\%)$ & -0.620 & -0.674 & 0.509 & & & & & & & & & & \\
\hline K-Fedspaths + Plagio. (\%) & -0.551 & -0.807 & 0.570 & 0.460 & & & & & & & & & \\
\hline Magnetic Susceptibility (SI) & -0.607 & -0.640 & 0.663 & & 0.678 & & & & & & & & \\
\hline TOM (\% wt) & -0.484 & -0.411 & 0.330 & 0.625 & & 0.526 & & & & & & & \\
\hline $\mathrm{Al}$ (rel. cont) & -0.760 & -0.728 & 0.687 & 0.641 & 0.602 & 0.624 & 0.411 & & & & & & \\
\hline $\mathrm{Si}$ (rel. cont) & -0.754 & -0.794 & 0.787 & 0.520 & 0.545 & 0.661 & 0.456 & 0.426 & & & & & \\
\hline $\mathrm{K}$ (rel. cont) & -0.806 & -0.784 & 0.744 & 0.640 & 0.602 & 0.624 & 0.592 & 0.976 & 0.961 & & & & \\
\hline $\mathrm{Ti}$ (rel. cont) & -0.836 & -0.812 & 0.882 & 0.509 & 0.587 & 0.657 & 0.584 & 0.927 & 0.955 & 0.943 & & & \\
\hline $\mathrm{Fe}$ (rel. cont) & -0.786 & -0.732 & 0.689 & 0.866 & 0.528 & 0.697 & 0.628 & 0.868 & 0.794 & 0.851 & 0.828 & & \\
\hline \multicolumn{14}{|l|}{ Juniperus (\%) } \\
\hline \multicolumn{14}{|l|}{ Abies + Cedrus $(\%)$} \\
\hline Deciduous Quercus (\%) & 0.361 & 0.361 & -0.338 & & & & & -0.342 & -0.406 & -0.407 & -0.392 & -0.316 & \\
\hline Everg. Quercus + Pinus (\%) & 0.335 & 0.428 & -0.496 & & -0.410 & & & & & & & & \\
\hline Steppic (\%) & -0.495 & -0.572 & 0.616 & & -0.708 & 0.648 & & 0.387 & 0.553 & 0.470 & 0.578 & 0.408 & -0.674 \\
\hline \multicolumn{14}{|l|}{$\begin{array}{l}\text { Aquatic + subaquatic }(\%) \\
\delta^{18} \mathrm{O} \text { carbonate (PDB } \% \text { ) }\end{array}$} \\
\hline $\mathrm{AP} \%$ & 0.51 & & & & & -0.49 & & & & & & & \\
\hline
\end{tabular}

Environmental variables were initially reconstructed with different depth resolution and along different core length. Thus, data were re-sampled with a common depth-scale $(20 \mathrm{~cm})$ between 64 and $3364 \mathrm{~cm}$. This procedure shortens the high resolution and the longest records, but the resulting matrix, based on 166 core levels, is well-suited for numerical analyses. Environmental variables were translated into standard deviation units (s.d.u.). Significant simple linear correlation coefficients between individual variables are plotted in Table 3. Data integration was performed using the Analyseries 2.0 software (Paillard et al., 1996).

We first performed a PCA on the multiproxy matrix $\left(\mathrm{ACP}_{\mathrm{MP}}\right)$ of 22 variables listed in Table 2 . Scores of two first principal components PC1 and PC2 (63.3\% of total variane) and the projection of the variables in factorial plans 12 are plotted in Fig. 8a and b. PC1 scores confirm the 2 poles (end-members) of sediment fraction, carbonate $(\mathrm{Ca}$, calcite + aragonite) v. all other sediment components (detrital), already highlighted by Develle et al. (2011). Note that carbonate-dominated units are mainly composed of authigenic calcite. Axis 1 shows close linkages between carbonate and arboreal vegetation lying on the negative side, Mediterranean evergreen Quercus having the strongest contribution among tree taxa. The positive loading of steppe and siliciclastic (and dolomite) components shows that high contribution of eolian and local detrital influxes to sedimentation prevailed during periods of open vegetation. PC2 differentiates the lower $(>1870 \mathrm{~cm})$ and upper halves of the sequence. This asymmetry is largely due to the strong positive loading on Axis 2 of pollen from cool conifer forests (Juniperus, Cedrus, Abies) and aquatic-palustral plants which are poorly represented above $1870 \mathrm{~cm}$. The $\delta_{\mathrm{c}}$ values steer Axis 2 on the negative side. The positive correlation between TOM and detrital elements and the distance between aquatic-palustral plant pollen and TOM in factorial plans 1-2 suggests that, in most samples, TOM is derived from the catchment soil erosion rather than from organic production in the local waterbody. The low contribution of $\delta_{\mathrm{c}}$ and tree pollen from cool wet forests, Pinus and deciduous Quercus to Axis 1 suggest that $\delta_{\mathrm{c}}$ fluctuations and these tree types are partly independent of the sediment components.

We then computed a PCA $\mathrm{PCd}_{\text {Sed }}$ based on all sedimentological proxies. Figure 9a shows PCASed-Axis 1 (67.8\% of total variance) and resampled $\mathrm{PCA}_{\mathrm{B}}$-Axis 1 based on pollenderived biomes (see Sect. 4.1). Aquatic/palustral assemblage and $\delta^{18} \mathrm{O}$ are excluded from this comparison. Visual observation reveals a close link between the highest $\mathrm{PCA}_{\mathrm{B}}-\mathrm{Axis} 1$ and the lowest $\mathrm{PCA}_{\text {Sed }}$-Axis 1 values, except between $\sim 500$ and $\sim 200 \mathrm{~cm}$ when detrital carbonates became abundant. Drastic decreases in $\mathrm{PCA}_{\mathrm{B}}$-Axis 1 may be partly explained by the lowering of the upper tree line during the coldest periods, but lithofacies above $500 \mathrm{~cm}$ indicate that these shifts primarily reflect a local drying. A cross-correlation between the $\mathrm{PCA}_{\mathrm{B}}$-Axis 1 and $\mathrm{PCA}_{\text {Sed }}$-Axis 1 scores (Fig. 9b) confirms the negative correlation between the two depth/timeseries by a narrow peak centred on depth-lag $0(-48.6 \%$ ), reflecting the co-evolution of both signals during the whole sequence.

Relationships between isotope $\left(\delta_{\mathrm{c}}\right)$ and vegetation dynamics (Fig. 9c and d) are more complex. PCA $A_{B}$-Axis 1 and $\delta_{\mathrm{c}}$ run roughly parallel during the coloured detrital-rich intervals. Overall decrease/increase in $\delta_{\mathrm{c}}$ when $\mathrm{PCA}_{B}$-Axis 1 increased/decreased can be classically interpreted as reflecting wetting/drying trends, respectively (e.g., in the intervals $\sim 2750-1840$ and 780-200 cm). Conversely, clear antiphasing occurred during periods of sharp increases in $\mathrm{PCA}_{\mathrm{B}}$-Axis (development of arboreal vegetation implying relatively high water availability), associated with steep and large $\delta_{\mathrm{c}}$ enrichments. Such discrepancies have already been pointed out in several post-glacial records from eastern Mediterranean 

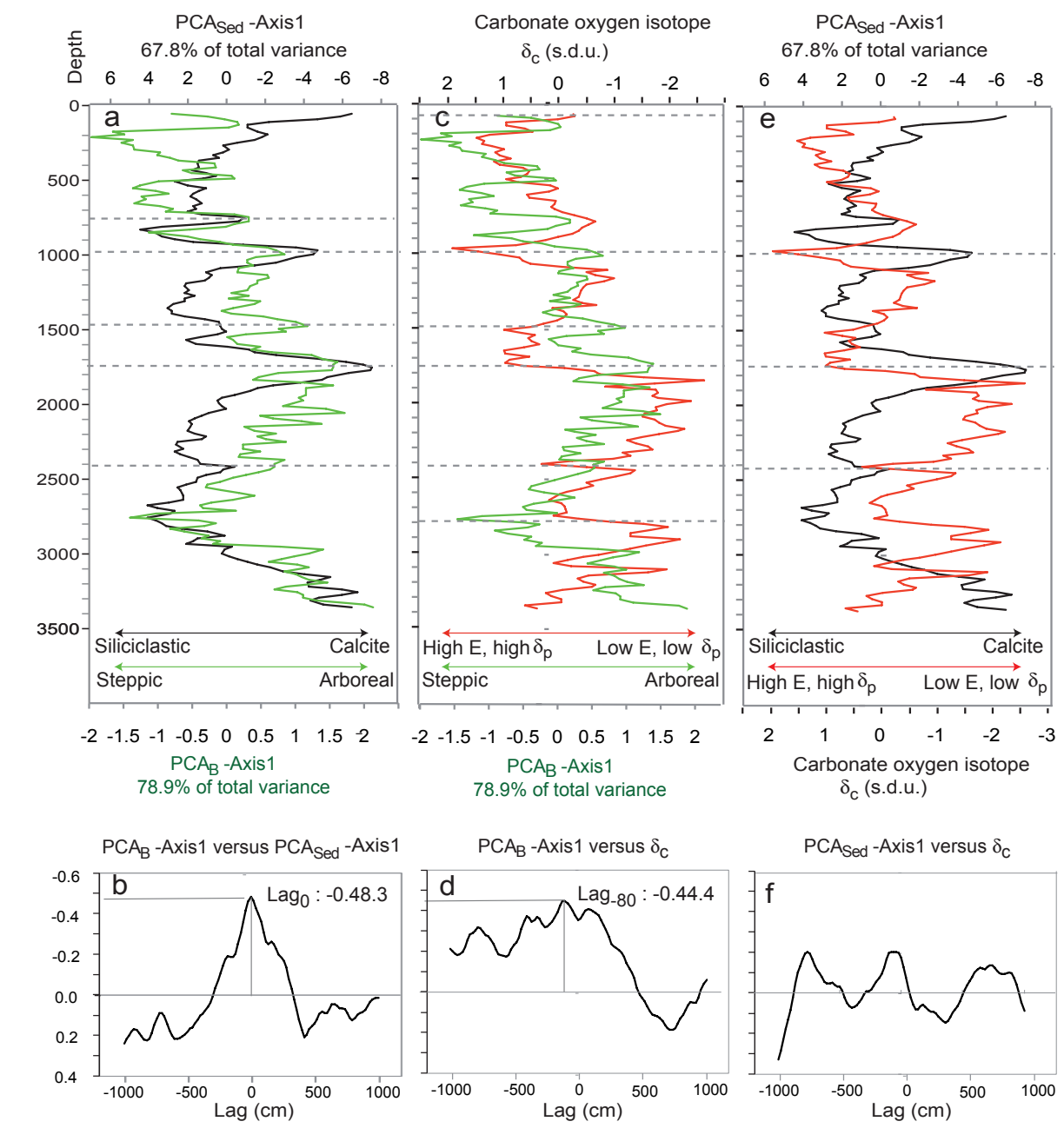

Fig. 9. Relationships between pollen, sediment properties and isotope data. (a) PCA $\mathrm{B}-\mathrm{Axis} 1$ and PCA $\mathrm{A}_{\mathrm{Sed}}-\mathrm{Axis}_{1} 1$ scores versus depth. (b) Cross correlation between these two depth series. (c) Carbonate oxygen isotope, $\delta_{\mathrm{c}}$ (in standard deviation units, s.d.u.) and PCA $\mathrm{B}-\mathrm{Axis} 1$ versus depth. (d) Cross correlation between these two depth series. (e) PCA $\mathrm{Sed}_{\mathrm{S}}$-Axis 1 and $\delta_{\mathrm{c}}$ (in standard deviation units, s.d.u.). (f) Cross correlation between these two depth series.

lakes. They have been attributed either to a disequilibrium between climate and vegetation (e.g., at Lake Golhisar, Turkey, Fig. 1; Eastwood et al., 2007), or changes in precipitation seasonality (at Lakes Zeribar and Mirabad, NW Iran, Fig. 1; Stevens et al., 2001, 2006). As discussed above from both pollen and isotope data, we favour the hypothesis of seasonal increased hydrological and thermal contrasts with wet cool winters, possibly a longer rainy season, and very dry warm summers generating strong evaporative effects in both the drainage area and the waterbody. Due to reversed relationships between these two proxy depth-series through time, the cross-correlation for the whole record does not show narrow peak, but an overall correlation (maximum negative correlation: -44.4 , with a small depth lag of $80 \mathrm{~cm}$ ). Links between PCA Sed $_{\text {-Axis }} 1$ and $\delta_{\mathrm{c}}$ also vary with depth (Fig. 9e and f). These two series are clearly in antiphase during carbonate-rich intervals, but intervening periods do not show clear patterns.

\subsection{Major environmental changes through time}

The major environmental changes observed at Yammoûneh, as constrained by all analysed indicators (Figs. 5-7), are now discussed versus time (Fig. 10a-g), according to our age model. Figure 10 also displays (with independent time scales) orbital forcing expressed by eccentricity and summer/winter insolation at $34^{\circ} \mathrm{N}$ (Fig. 10h; Berger, 1978) and MISs reflecting global ice volume (Fig. 10i; Martinson et al., 1987).

The lowest part of the Yammoûneh profile is poorly resolved, partly because several gaps in core recovery (Fig. 4a). The carbonate-rich interval $3670-2970 \mathrm{~cm}$ is assigned to MIS 7 (240-190 ka). Its base $(3670-3300 \mathrm{~cm} ; \sim 240$ $220 \mathrm{ka}$ ) is characterised by the maximum development of arboreal vegetation dominated by cool conifer forests and temperate deciduous trees indicating cool and wet conditions. A permanent waterbody with high biogenic and in 


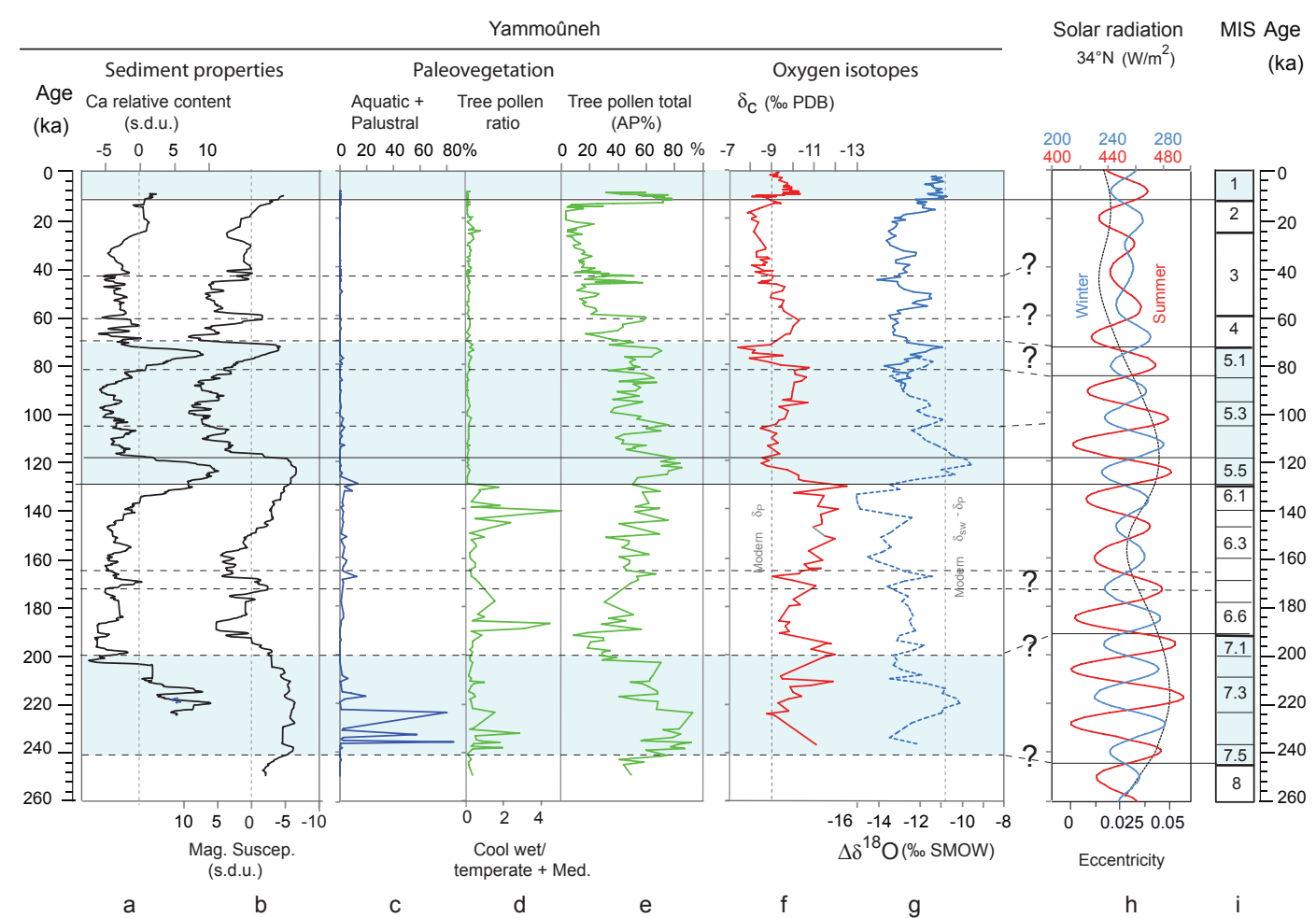

Fig. 10. Major proxies from Yammoûneh versus time according to our age model, and external paleoclimate data (on independent time scale). (a) Ca relative content. (b) Magnetic susceptibility. For clarity, these two proxies are plotted as the first component factor of a Singular Spectrum Analysis (performed using the Paillard et al., 1996, software) and representing 84 and $92.3 \%$ of the total variance, respectively (s.d.u.: standard deviation units). (c) Aquatic + palustral plant pollen (percentage of total pollen grains). (d) Ratio of the pollen percentages (percentage of terrestrial pollen) of cool conifer forests/temperate to Mediterranean forests. (e) Total tree pollen percentages. (f) $\delta_{\mathrm{c}}$. (g) $\Delta \delta^{18} \mathrm{O}$ (as in Fig. 7f). (h) Orbital eccentricity and summer/winter insolation at 34 $\mathrm{N}$ (Berger, 1978); (i) MISs (Martinson et al., 1987). Questions marks between (g) and (h) suggest links between major environmental changes at Yammoûneh and global climate changes.

situ carbonate production implies a substantial rise of the local shallow water table. High $\Delta \delta^{18} \mathrm{O}$ values around $3250 \mathrm{~cm}$ (220 ka?) suggest heavy rainfall. Periods with high $\delta_{\mathrm{c}}$ values may result from the ${ }^{18} \mathrm{O}$ enrichment of inflowing water due to a relatively long water residence time in the permanent waterbody, and/or high summer evaporation rate. We interpret this period as reflecting the highest P-E balance of the whole record. Above $3300 \mathrm{~cm}$, a negative shift of aquatic-palustral plant pollen, and the opening of the vegetal cover inducing enhanced erosion and detrital input, record a slight decrease in effective moisture which remained, however, high enough to allow mountain and mixed temperate forest elements to grow. This generally wet interval apparently coincides with period of maximum insolation seasonal contrasts. Its termination is not clearly identified in our record.

The period assigned to MIS $6(\sim 190-130 \mathrm{ka})$ is represented from $\sim 2950$ to $1850 \mathrm{~cm}$ by silty clays interrupted by a marly layer around $2450 \mathrm{~cm}(\sim 170 \mathrm{ka}$ ? $)$ and progressively enriched in carbonate above $2150 \mathrm{~cm}(\sim 150 \mathrm{ka}$ ?). At the base, eolian material prevailed in detrital sediment when the landscape was predominantly steppic. After $\sim 180 \mathrm{ka}$, cool conifer and/or temperate deciduous forests developed, aquatic vegetation reappeared, and $\delta_{\mathrm{c}}$ shifted to reach the lowest values of the profile toward the end of this interval. This suggests an overall increase in local efficient moisture, although $\Delta \delta^{18} \mathrm{O}$ decreased possibly due to low temperature (and, thus, low $\delta_{\mathrm{P}}$ ). This general trend is punctuated by two events. At $\sim 2450 \mathrm{~cm}(\sim 170 \mathrm{ka}$ ), a narrow peak of carbonate, an increase in marsh plant pollen, and a juniper decline in favour of deciduous oaks suggest a rise of the water table and a moderate warming. This event also shows sharp $\delta_{\mathrm{c}}$ and $\Delta \delta^{18} \mathrm{O}$ positive shifts, which may reflect an interval of amplified seasonal thermal and hydrological contrasts possibly coincident with high solar radiation seasonality. Above $2150 \mathrm{~cm}(\sim 150 \mathrm{ka}$ ?), junipers became dominant again under the cold conditions of late MIS 6 . Even if mean annual precipitation was low, the local available moisture was sufficient to sustain arboreal vegetation, wetlands around the core site and depleted $\delta_{\mathrm{c}}$ values when low glacial temperature minimized evaporation and evapotranspiration.

The last interglacial maximum, MIS $5.5(\sim 1850$ $1680 \mathrm{~cm} ; \sim 130-120 \mathrm{ka}$ ), is the period of optimal conditions for authigenic carbonate production culminating at $\sim 124 \mathrm{ka}$. At $\sim 129 \mathrm{ka}$, an abrupt decline of junipers replaced by deciduous oaks first indicates a warming. Then, a rapid expansion of mesic Mediterranean forests fingerprints the 
establishment of a typical Mediterranean climate. Aquatic and hydrophilous plant pollen disappeared and a dramatic increase in $\delta_{\mathrm{c}}$ values occurred, which, at a first glance, could evoke a drying. Such an interpretation disagrees with very high tree pollen percentages and a synchronous large and positive shift of $\Delta \delta^{18} \mathrm{O}$. We interpret this period as reflecting strong orbital-induced seasonal hydrological and thermal contrasts, with cool, strongly rainy winters and possibly a longer rainy season, but very warm, dry summers inducing relatively low mean annual effective moisture inhibiting the growth of mountain and temperate trees. MIS 5.5 coincides with a major change in Yammoûneh environments: after $130 \mathrm{ka}$, the cool-wet conditions of MIS 7 and late MIS 6 never appeared again.

From $\sim 120$ to $\sim 80-75 \mathrm{ka}$, finely banded olive gray silty clay prevailed. Grain-size and colour gradients in each band evoke episodic runoff events followed by quiet decantation periods. The detrital accumulation is interrupted by an interval enriched in carbonate around $1500 \mathrm{~cm}(\sim 105 \mathrm{ka})$ and passes progressively to a light gray marl above $1200 \mathrm{~cm}$ $(\sim 85 \mathrm{ka})$. Open vegetation tends to replace forested landscapes, but this trend is not linear. Peaks of mixed arboreal pollen coincide with carbonate-enriched phases, and reflect wetter conditions than during intervening steppe intervals. These peaks are synchronous with sharp $\delta_{\mathrm{c}}$ enrichments and $\Delta \delta^{18} \mathrm{O}$ increases. The last one resembles MIS 5.5 in its mineral composition and isotope pattern. These two peaks are attributed to MIS 5.3 and MIS 5.1, respectively, although the later is slightly too young in our time scale.

During the last glacial period, MIS 4, 3 and early MIS 2 ( $\sim 970-225 \mathrm{~cm}, \sim 75-16 \mathrm{ka}$ ), olive gray clay first dominates and the maximum contribution of eolian dust to sedimentation appears around $900 \mathrm{~cm}(\sim 70-65 \mathrm{ka})$. At $\sim 425 \mathrm{~cm}$ ( $\sim 40 \mathrm{ka}$ ), the greenish clay passes abruptly to strongly oxidized ocher, reddish clayey silt which contains limestone gravels and carbonate concretions suggesting frequent desiccations at the core site. An increase in carbonate content, mainly detrital, is attributed to physical erosion of the watershed limestones in an environment almost devoid of vegetation. Pollen data clearly show a shift toward steppic-desertic environments consistent with the $\delta_{\mathrm{c}}$ increase, interrupted by two moderate humid pulses (around 730 and $500 \mathrm{~cm} ; \sim 60$ and $45 \mathrm{ka}$ ?). The local water availability reached the minimum of the whole record between $\sim 21$ to $16 \mathrm{ka}$ (LGM and Termination 1; MIS 2). Karstic groundwater circulation was considerably reduced. This does not necessarily mean extremely low regional precipitation, but may reflect water storage in Mt Lebanon glaciers and permafrost in the Mnaïtra plateau when temperature was at least $10^{\circ} \mathrm{C}$ lower than today. Indeed, permanent glaciers, evidenced by moraines above $2000 \mathrm{~m}$ a.s.l. on the western flank of Mt Lebanon, occurred during the LGM (L. Benedetti, personal communication, 2011). The last glacial stage clearly differs from MIS 6 in its trend towards local arid conditions.
After $\sim 16 \mathrm{ka}$, the post glacial warming is associated with the rapid re-establishment of humid conditions in the Yammoûneh basin, in response to ice melting and enhanced precipitation. This wetting is evidenced by, successively, a step-wise decrease in $\delta_{\mathrm{c}}$ from 16 to $8.5 \mathrm{ka}$ (Develle et al., 2010), the abrupt development of deciduous oaks around 13 $\mathrm{ka}$, and the deposition of a white lacustrine marl rich in rests of aquatic organisms after $11.5 \mathrm{ka}$. The wetting optimum is reached from $\sim 11$ to $8.5 \mathrm{ka}$, in phase with $\mathrm{S} 1$. In the core, the Holocene is truncated at $\sim 7.5 \mathrm{ka}$, but a trend toward aridity starting at $\sim 7 \mathrm{ka}$ is registered by the isotope record in trench TR02 (Develle et al., 2010). This early Holocene wetting was shown at other sites from Lebanon (see site location in Fig. 1) by changes in growth rate, $\delta^{18} \mathrm{O}$ and $\delta^{13} \mathrm{C}$ in a $12 \mathrm{ka}$ speleothem from Jeita Cave (Verheyden et al., 2008), and by the $\sim 15$ ka-pollen records from the Aammish marsh in the Bakka Plain (Hajar et al., 2008, 2010). Pollen data from the Ghab Valley, Syria (Yasuda et al., 2000) show similar trends.

\section{Discussion and conclusions}

The Yammoûneh record represents the first long multi-proxy paleoenvironmental-paleoclimatic reconstruction based on a single sedimentary sequence and on both biotic and hydrological indicators in the Levant. The combination of pollen, sediment properties and isotope data allowed us to crosscheck the information derived from independent proxies and to strengthen the overall interpretation of paleoenvironmental changes. This record covers three Interglacials and two full glacial stages. It fills a geographical gap in data coverage as no other long record is available in northern Levant. Main environmental characteristics of the Yammoûneh basin during interglacial peaks and glacial periods can be drawn as follows.

\subsection{Main characteristics of interglacial and glacial stages at Yammoûneh}

Interglacial maxima (early-mid MIS 7, MIS 5.5 and early MIS 1) experienced relatively high effective moisture in both the surface and groundwater drainage areas. This is clearly evidenced by sharp increases and dominance of forested landscapes, leading to reduced erosion in the basin slopes. Forested stages are closely correlated with periods of authigenic carbonate sedimentation in the local waterbody which sustained a rich and diversified biocenose. Synchronous and steep $\delta_{c}$ increases can be reconciled with enhanced mean annual moisture when changes in seasonality are taken into account. By analogy with the relatively well-dated early Holocene and MIS 5.5 periods, we suggest (Fig. 10) that other interglacial wet pulses (MIS 5.3-MIS 5.1) and short-lived warmer/wetter events punctuating glacial periods (e.g., $\sim 170 \mathrm{ka}$ ) also match phases of high seasonal insolation contrasts. Despite these common features, the three 
interglacial maximums differ significantly: very wet and cool conditions prevailed during the MIS 7 peaks; MIS 5.5 is characterised by typical Mediterranean environments with very wet winter and warm evaporative summer conditions, whereas a more temperate wet climate established during early MIS 1.

Glacial periods, characterised by the dominance of coloured silty clay in the sediments, exhibit the highest weight percentages of wind-blown particles, indicating a strong contribution of eolian dust to sedimentation. Forest vegetation cover was generally reduced compared to interglacial stages, favouring local erosion. Environmental conditions evolved, however, in opposite directions during the penultimate and the Last Glacial period. All proxy data reveal an overall wetting during MIS 6 culminating toward the end of this stage, while a drying trend took place during MIS4-2, leading to extremely harsh LGM conditions. We suggest that, under the very cold LGM climate, water was stored by ice in frozen soils in the Yammoûneh depression and in glaciers in the aquifer recharge zone, resulting in extremely low local liquid water availability. As for successive Interglacials, the glacial stages were not identical.

Our record shows an overall decrease in local available water: episodes of maximum moisture occurred during earlymid MIS 7; MIS 6 was wetter than the late glacial stage; the amplitude of wet pulses decreased from MIS 5.5 to the early Holocene. The basin infilling by lake sediments might explain the almost total disappearance of permanent waterbodies after $130 \mathrm{ka}$ and frequent desiccation periods during MIS 2, but not changes in terrestrial vegetation. The longterm aridity trend coincides with a weakening of the seasonal insolation contrasts linked to the decreasing amplitude of the eccentricity cycle. It is as though the Yammoûneh water balance was partly controlled by the amplitude of the seasonal insolation contrast and the relative intensity of winter cooling.

\subsection{Comparison with other EMS records}

Placed in its regional context, the Yammoûneh record suggests similarities and differences with other records from the EMS region and raises a series of questions on the underlying mechanisms. Some key regional records are illustrated in Fig. 11, which also displays two proxy curves from Yammoûneh for comparison. Sites cited below are located in Fig. 1.

The Yammoûneh evolution generally agrees with data from northeastern Mediterranean and NW Iran, except during MIS 6. This is exemplified (Fig. 11a-c) by pollen records from Albania (L. Ohrid, Lézine et al., 2010), Greece (Tenaghi Philippon, Tzedakis et al., 2006) to NW Iran (L. Urmia, Djamali et al., 2008). During glacial periods, steppe landscapes took place under cool, dry conditions. Nevertheless, several east Mediterranean lakes (e.g., Konya in Turkey, L. Urmia) have experienced relatively high level stands attributed to substantial temperature lowering reducing evaporation loss and enhanced runoff when an open vegetation cover prevailed (Roberts et al., 1999; Djamali et al., 2008). During interglacial peaks, maximum tree pollen percentages reflect warm conditions and higher precipitation from the mid-latitude westerly system. Changes in seasonality were proposed by several authors to explain Holocene climate in the region (Stevens et al., 2001, 2006; Magny, 2007; Tzedakis, 2007; Peyron et al., 2010; Djamali et al., 2010). At Yammoûneh, sharp $\delta_{\mathrm{c}}$ increases in phase with arboreal pollen peaks, attributed to enhanced seasonal thermal and hydrological contrasts, suggest that the hypothesis of seasonal changes is valid for older interglacial stages (e.g., MIS 5.5 and MIS 5.1). The specific case of Lake Ohrid, a mountainous karstic lake, is interesting to compare with Yammoûneh: authigenic calcite precipitated during warm phases, when the karstic system was active and forests developed in the catchment area, while detrital siliciclastic particles accumulated and forests are replaced by steppic landscapes during the last glacial period due to strong deficits in available water stored as ice in the mountains (Lézine et al., 2010).

Our record also shares some features with stable isotope spelothem records from western Israel (Peqi'in and Soreq Caves, Fig. 11f) as interpreted by Bar-Matthews et al. (2003). These authors thought that the records integrate the effects of the moisture source (the EMS surface water), rainfall amount and temperature: low/high $\delta^{18} \mathrm{O}$ reflect wet/dry conditions during interglacial/glacial periods (Bar-Matthews et al., 2003). Paleoprecipitation reconstructions at Soreq (based on present-day relationships between rainwater $\delta^{18} \mathrm{O}$ and rainfall amount) suggest very high rainfall around $125 \mathrm{ka}$ (MIS 5.5) and a precipitation amount close to modern during early MIS 5.1 (Bar-Matthews et al., 2003; Bar-Matthews and Ayalon, 2004), as proposed from our $\Delta \delta^{18} \mathrm{O}$ calculations (Figs. $10 \mathrm{~g}$ and $11 \mathrm{e}$ ). Sharp negative $\delta^{18} \mathrm{O}$ shifts fit EMS sapropel events linked to increased Nile River discharge and, thus, to enhanced monsoon strength (Bar-Matthews et al., 2000). These interpretations are in line with marine pollen records from the southern Levantine basin (core MD84642, Cheddadi and Rossignol-Strick, 1995; core MD-9509; Langgut, 2011). Another striking point arising from both the Soreq and Yammoûneh records is the difference between the penultimate and the last glacial period. At Soreq, the $\delta^{18} \mathrm{O}$ and $\delta^{13} \mathrm{C}$ isotopic records from Soreq Cave suggest that, during the entire MIS 6, although the climate was as cold as much of the last glacial, the conditions were never as dry (Ayalon et al., 2002). This Soreq record also shows two major negative shifts in the $\delta^{18} \mathrm{O}-\delta^{13} \mathrm{C}$ values $(\sim 178$ and $\sim 152 \mathrm{ka})$ interpreted as dramatic increases in rainfall amount, related to the EMS sapropel S6 (the only sapropel event occurring during a glacial phase) and to another EMS event not large enough to form sapropel Bar-Matthews et al., 2003), both associated with increased African monsoon (Fig. 11f, $\mathrm{k}, 1)$. The wetting events observed at Yammoûneh at $\sim 170$ and $\sim 150 \mathrm{ka}$ in our time scale $(2450$ and $2150 \mathrm{~cm})$ could 


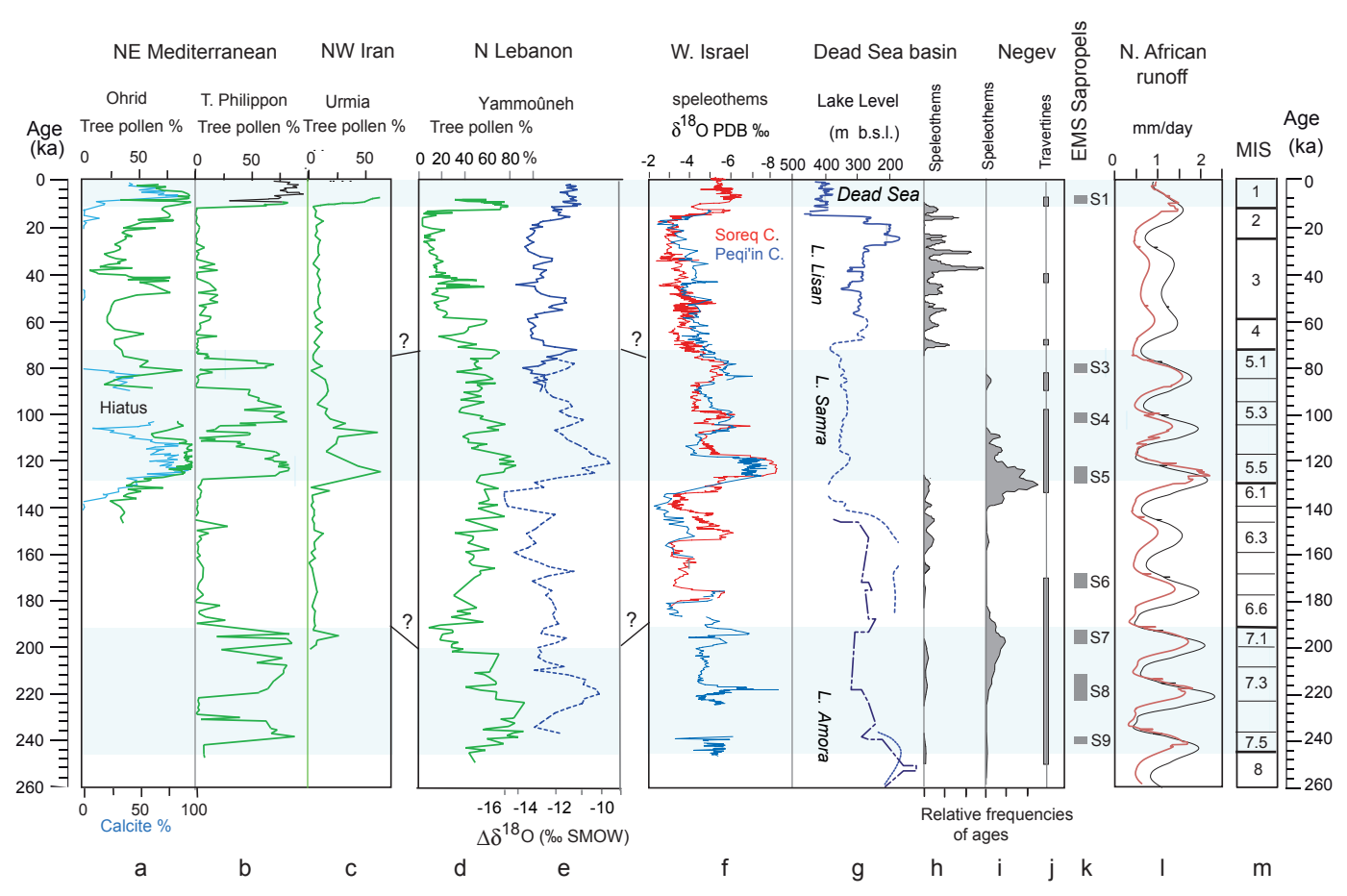

Fig. 11. Environmental changes in the eastern Mediterranean region. (a)-(c) Tree pollen percentages in sediments from a): Lake Ohrid, Albania (Lézine et al., 2010); (b) Tenaghi Philippon, Macedonia (Tzedakis et al., 2006); (c) Lake Urmia, NW Iran (Djamali et al., 2008). (d)-(e) Yammoûneh proxy data. (d) Tree pollen percentages (as Fig. 10e); (e) $\Delta \delta^{18} \mathrm{O}$ : (as Fig. 10g). (f) $\delta^{18} \mathrm{O}$ record from Soreq and Peqi'in Caves speleothems, western Israel (Bar-Matthews et al., 2003). (g) Lake level fluctuations of the Dead Sea and its predecessors (Waldmann et al., 2010). (h) Relative frequency of ages of speleothem deposition in the Dead Sea basin (Lisker et al., 2010). (i) Relative frequency of ages of speleothem deposition in the Negev (Vaks et al., 2010). (j) Periods of travertine deposition deposition in the Arava valley (Waldmann et al., 2010). (k) EMS sapropel events (Ziegler et al., 2010). (l) Simulated North African runoff to the eastern Mediterranean basin as an indicator of African monsoon (Ziegler et al., 2010). Results from the CLIMBER-2 model using orbital forcing only (black curve), orbital forcing + varying NH ice sheets and greenhouse gas concentrations (red curve). (m) MISs (Martinson et al., 1987).

correspond to these Soreq-EMS climatic changes. Keeping in mind that the tropical influence of the Nile River extent as north as Cyprus in the Levantine basin during MIS 3 and MIS 1 (Almogi-Labin et al., 2009), an indirect tropical influence superimposed to the dominant role of the North Atlantic-Mediterranean system might have reached the western Levant by times. A potential impact on this region of the remote Eurasian ice sheet, much larger at $160-130 \mathrm{ka}$ than during the LGM, and of the resulting huge proglacial lakes over central Europe (Svenden et al., 2004; Mangerud et al., 2004) might also be considered.

At the northern limits of the Saharan-Arabian desert, in Negev and the Arava Valley, sporadic events of deposition of speleothems (Vaks et al., 2010; Fig. 11i) and travertine (Waldmann et al., 2010: Fig. 11j) indicate episodes of enhanced effective precipitation in phases with periods of intensified monsoon, schematized by simulated changes in North African river discharge to the EMS and related EMS sapropel events (Fig. 11k and 1; Ziegler et al., 2010). These short wet pulses have suggested intrusions of humidity from southern sources during interglacial periods (Waldmann et al., 2010), or simultaneous intensification of monsoon and Atlantic-Mediterranean cyclones (Vaks et al., 2010).

Thus, evidence emerging from the regions evoked above and the Yammoûneh record appears to be in agreement in suggesting dry-cool glacial periods (except MIS 6) and wetter-warm interglacial conditions. In contrast, in the rain shadow of the Judean mountains, the deep, warm Dead Sea basin (DSB), behaved in opposite directions, as indicated by cave stromatolites and periods of speleothem growth/nondeposition (Vaks et al., 2003, 2006, 2010; Fig. 11h; Lisker et al., 2008, 2010) and lake level fluctuations (Fig. 11g; Waldmann et al., 2010) of the Dead Sea (Enzel et al., 2003; Migowski et al., 2006) and its predecessors (Lake Lisan: Bartov et al., 2003; Hazan et al., 2005; Bookmann et al., 2006; Lake Samra: Waldmann et al., 2009; Lake Amora: Torfstein et al., 2009). The only period when the high altitude, small, groundwater-fed Yammoûneh basin roughly evolved in parallel with the DBS is MIS 6. In the DSB, local winds predominate on the large-scale wind components, and local temperature and related evaporation rates are crucial factors controlling the Dead Sea water balance 
(Alpert et al., 1997). According to Enzel et al. (2008), increased water availability in the DSB during glacial phases reflect increased rainfall due to the southward deflection of moist westerlies southwards by the presence of ice sheets, as showed by coupled ocean-atmosphere circulation models for the LGM (e.g., Li and and Battisti, 2008; Lainé et al., 2009). An alternative explanation was proposed by Vaks et al. (2003) who suggested reduced evaporation rates during the cold glacial phases leading to a higher P-E balance, and vice-versa during interglacials. This second hypothesis appears consistent with the recent Dead Sea water level lowering, induced by the current warming which results in lower local air humidity and higher evaporation (Shafir and Alpert, 2010).

To sum-up, all records from the eastern Mediterranean region, from southeastern Europe to the northern SaharaArabian desert, are in phase with long-term orbitally-induced temperature fluctuations, ice sheet waxing/waning in the Northern Hemisphere, and climatic changes in the North Atlantic system. These linkages reflect, however, different climatic mechanisms, different moisture sources, that resulted in different responses to global changes of individual proxies and individual hydrosystems.

\subsection{Perspectives}

Further work is required to obtain additional age control points, constrain changes in sedimentation rates and to improve the chronology of environmental changes observed at Yammoûneh.

The impact of seasonal changes in precipitation and temperature on individual proxies should be investigated using modern reference data from the region. Although modern analogues for the glacial periods are missing in the region, quantification of paleoclimatic variables should be attempted.

Hydrological modelling, associated with further investigation of the Mt Lebanon glacier evolution, should help better understand the functioning of the Yammoûneh system.

Our record is based on a single site and its specific climatic and hydrological setting. Other long records from northern Levant and climate modelling are needed to disentangle the effects of local, regional and global climatic-hydrological factors on the basin evolution. Solid scenarios could then be proposed to explain the potential spatial heterogeneity in available moisture in the Levant region.

Acknowledgements. We are grateful to P. Tapponnier, Singapur University and A. Sursock, CNRG-CNRS-Lebanon, who initiated the investigation of the Yammoûneh basin. We thank colleagues from the IPG-P, from the CNRG, and A. Elias, American University in Beyrouth, for their help during fieldwork and fruitful discussions. Thanks are due to M. Decobert and the SETEL team (CEREGE, CNRS) for coring, to D. Kaniewski for his help in the biomization procedure, and to C. Sonzogni (CEREGE), T. Otto and J.-J. Dedoubat (ECOLAB) for technical assistance. L. Lisker
(Hebrew University of Jerusalem) and M. Ziegler (Lamont-Doherty Earth Observatory) kindly transmit us their data files on DSB-basin speleothems and simulated African river runoff. We thank the editor M. Fuchs, an anonymous reviewer who took time to comment our initial version and warmly acknowledge N. Roberts for his constructive criticisms on our manuscript. Financial support came from the CNRS-France, the CNRS-Lebanon, the IPG-P, the French Embassy in Lebanon, the CEDRE French-Lebanese programme and the French project INSU-LEFE-EVE-PALEOLIBAN.

Edited by: M. Fuchs

\section{References}

Abi-Saleh, B. and Safi, S.: Carte de la végétation du Liban, Ecologia Mediterranea, 14, 123-141, 1988.

Affek, H. P., Bar-Matthews, M., Ayalon, A., Matthews, A., and Eiler, J. M.: Glacial/interglacial temperature variations in Soreq cave speleothems as recorded by "clumped isotope" thermometry, Geochim. Cosmochim. Acta, 72, 5351-5360, 2008.

Almogi-Labin, A., Bar-Matthews, M., Shriki, D., Kolosovsky, E., Paterne, M., Schilman, B., Ayalon, A., Aiznshtat, Z., and Matthews, A.: Climatic variability during the last $90 \mathrm{ka}$ on the southern and northern Levantine basin as evident from marine records and speleothems, Quaternary Sci. Rev., 28, 2882-2896, 2009.

Alpert, P. and Ziv, B.: The Sharav cyclone: observations and some theoretical considerations, J. Geophys. Res., 94, 18495-18514, 1989.

Alpert, P., Shafir, H., and Issahary, D.: Recent changes in the climate of the Dead Sea Valley, Climatic Change, 7, 1-25, 1997.

Aouad, A., Travi, Y., Blavoux, B., Job, J. O., and Najem, W.: Etude isotopique de la pluie et de la neige sur le Mont Liban: premiers résultats, Hydrol. Sci., 49, 429-441, 2004.

Aouad, A., Job, J. O., Khalil, S., Touma, T., Bitar, C., Bocquillon, C., and Najem, W.: Snow in Lebanon: a preliminary study of snow cover over Mount Lebanon and a simple snowmelt model, Hydrol. Sci., 50, 555-569, 2005.

Ayalon, A., Bar-Matthews, M., and Kaufman, A.: Climatic conditions during marine oxygen isotope 6 in the eastern Mediterranean region from the isotopic composition of speleeothems of Soreq Cave, Israel, Geology, 30, 303-306, doi:10.1130/00917613(2002)030;0303:CCDMOI ;2.0.CO;2, 2002.

Bar-Matthews, M. and Ayalon, A.: Speleothems as paleoclimate indicators, a case study from Soreq Cave located in the eastern Mediterranean region, Israel, in: Past Climate through Europe and Africa, edited by: Battarbee, R. W., Gasse, F., and Stickley, C. S., Springer, Dordrecht, 363-391, 2004.

Bar-Matthews, M., Ayalon, A., and Kaufman, A.: Timing and hydrological conditions of sapropel events in the Eastern Mediterranean, as evident from speleothems, Soreq Cave, Israel, Chem. Geol., 169, 145-156, 2000.

Bar-Matthews, M., Ayalon, A., Gilmour, M., Matthews, A., and Hawkesworth, C. J.: Sea-land oxygen isotopic relationship from planktonic foraminifera and speleothems in the Eastern Mediterranean region and their implication for paleorainfall during interglacial intervals, Geochim. Cosmochim. Acta, 67, 3181-3199, 2003. 
Bar-Yosef, O.: The Natufian Culture in the Levant, Threshold to the origins of agriculture, Evol. Anthropol., 6, 169-177, 1998.

Bartov, Y., Goldstein, S. L., Stein, M., and Enzel, Y.: Catastrophic arid episodes in the Eastern Mediterranean linked with the North Atlantic Heinrich events, Geology, 31, 439-442, 2003.

Berger, A. L.: Long-term variations of daily insolation and Quaternary climatic changes, J. Atmos. Sci., 35, 2362-2367, 1978.

Besançon, J.: Le poljé de Yammoûné, Revue Libanaise de Géographie, 3, 3-62, 1968.

Bookman, R., Bartov, Y., Enzel, Y., and Stein, M.: The levels of the late Quaternary lakes in the Dead Sea basin: two centuries of research, in: New Frontiers in Dead Sea, Paleoenvironmental Research, edited by: Enzel, Y., Agnon, A., and Stein, M., Geological Society of America Special Paper, 401, 155-17, 2006.

Bottema, S.: The interpretation of pollen spectra from prehistoric settlements (with special attention to Liguliflorae), Palaeohistoria, 17, 17-35, 1975.

Bottema, S. and Van Zeist, W.: Palynological evidence for the climatic history of the Near East, 50,000-6,000 BP, in: Préhistoire du Levant, edited by: Cauvin, J. and Sanlaville, P., Paris-CNRS, 111-132, 1981.

Carto, S., Weaver, A. J., Hetherington, R., Lam, Y., and Wiebe, E. C.: Out of Africa and into an ice age: on the role of global climate change in the late Pleistocene migration of early modern humans out of Africa, J. Human Evol., 56, 139-151, 2009.

Castañeda, I., Shefuss, E., Pätzold, J., Sinninghe Damsté, J. S., Weldeab, S., and Schouten, S.: Millenial-scale sea surface temperature changes in the eastern Mediterranean (Nile River Delta region) over the last 27,000 years, Paleoceanography, 25, PA1208, doi:10.1029/2009PA001740, 2010.

Cheddadi, R. and Rossignol-Strick, M.: Easterm Mediterranean quaternary paloeclimates from pollen and isotope records of marine cores in the Nile cone area, Paleoceanography, 10, 291-300, 1995.

Craig, H.: The measurement of oxygen isotope paleotemperatures, in: Stable Isotopes in Oceanographic Studies and Paleotemperatures, edited by: Tongiorgi, E., Consiglio Nazionale delle Ricerche Laboratorio di Geologia Nucleare, Pisa, 166-182, 1965.

Daëron, M., Benedetti, L., Tapponnier, P., Sursock, A., and Finkel, R. C.: Constraints on the post-25-ka slip rate of the Yammoûneh fault (Lebanon) using in situ cosmogenic ${ }^{36} \mathrm{Cl}$ dating of offset limestone-clast fans, Earth Planet. Sc. Lett., 227, 105-119, 2004.

Daëron, M., Klinger, Y., Tapponnier, P., Elias, A., Jacques, E., and Sursock, A.: 12,000-year-long record of 10 to 13 paleoearthquakes on the Yammoûneh fault, Levant fault system, Lebanon, Bull. Seismol. Soc. Am., 97, 749-771, 2007.

Dayan, U., Ziv, B., Shoob, T., and Enzel, Y.: Suspended dust over southeastern Mediterranean and relation to atmospheric circulations, International J. Climatol., 28, 915-924, doi:10.1002/joc.1587, 2008.

Develle, A.-L.: Changement de l'environnement et du climat continental au cours des derniers cycles glaciaires/interglaciaires, Approche sédimentologique, géochimique et magnétique de la séquence lacustre du bassin de Yammoûneh (Liban), Unpublished $\mathrm{PhD}$ thesis, University of Aix-Marseille III, 2010.

Develle, A.-L., Herreros, J., Vidal, L., Sursock, A., and Gasse, F.: Controlling factors on a paleo-lake oxygen isotope record (Yammoûneh, Lebanon) since the Last
Glacial Maximum, Quaternary Sci. Rev., 29, 865-886, doi:10.1016/j.quascirev.2009.12.005, 2010.

Develle, A. L., Gasse, F., Vidal, L., Williamson, D., Demory, F., Van Campo, E., Ghaleb, N., and Thouveny, N.: A 250 ka sedimentay record from a small karstic lake in the northern Levant (Yammoûneh, Lebanon), Paleogeogr. Paleocl., 4-5, 10-27, doi:10.1016/j.palaeo.2011.02.008, 2011.

Di Castri F.: Mediterranean-type shrublands of the world, in: Mediterranean-Type Shrublands, edited by: di Castri, F., Goodall, D. W., and Specht, R. L., Elsevier, Amsterdam, 1-52, 1981.

Djamali, M., de Beaulieu, J.-L., Shah-hosseini, M., Anrieu-Ponel, V., Ponel, P., Amini, A., Alkani, H., Leroy, S. A. G., Stevens, L., Lahijani, H., and Brewer, S.: A late Pleistocene long pollen record from Lake Urmia, NW Iran, Quaternary Res., 69, 413420, 2008.

Djamali, M., Akhani, H., Andrieu-Ponel, V., Braconnot, P., Brewer, S., de Beaulieu, J.-L., Fleitmann, D., Fleury, J., Gasse, F., Guibal, F., Jackson, S. T., Lézine, A.-M., Médail, F., Ponel, P., Roberts, N., and Stevens, L.: Indian Summer Monsoon variations could have affected the early-Holocene woodland expansion in the Near East, Holocene, 20, 813-820, doi:10.1177/0959683610362813, 2010.

Dubertret, L.: Introduction à la carte géologique au 1/50000 du Liban, Notes et Mémoires du Moyen-Orient, 13, 345-403, 1975.

Ducassou, E., Capotondi, L., Murat, A., Bernasconi, S. M., Mulder, T., Gonthier, E., Migeon, S., Duprat, J., Giraudeau, J., and Mascle, J.: Multiproxy Late Quaternary stratigraphy of the Nile deep-sea turbidite system, Towards a chronology of deep-sea terrigeneous systems, Sediment. Geol., 200, 1-13, 2007.

Eastwood, W. J., Leng, M., Roberts, N., and Davis, B.: Holocene climate change in the eastern Mediterranean region: a comparison of stable isotope and pollen data from Lake Gölhisar, southwest Turkey, J. Quatern. Sci., 22, 327-341, 2007.

El Hakim, M.: Les aquifères karstiques de l'Anti-Liban et du nord de la plaine de la Bekaa: caractéristiques, fonctionnement, évolution et modélisation, d'après l'exemple du système karstique Anjar-Chamsine (Liban), Unpublished $\mathrm{PhD}$ thesis, University of Montpellier II, 2005.

Emeis, K. C., Schulz, H., Struck, U., Rossignol-Strick, M., Erlenkeuser, H., Howell, M. W., Kroon, D., Mackensen, A., Ishizuka, S., Oba, T., Sakamoto, T., and Koizumi, I.: Eastern Mediterranean surface water temperatures and $\delta^{18} \mathrm{O}$ during deposition of sapropels in the late Quaternary, Paleoceanography, 18, 1005, doi:10.1029/2000PA000617, 2003.

Enzel, Y., Bookman, R., Sharon, D., Gvirtzman, H., Dayan, U., Baruch, Z., and Stein, M.: Late Holocene climates of the Near East deduced from Dead Sea level variations and modern regional winter rainfall, Quaternary Res., 60, 263-373, 2003.

Enzel, Y., Amit, R., Dayan, U., Crouvi, O., Kahana, R., Baruch, Z., and Sharon, D.: The climatic and physiographic controls of the eastern Mediterranean over the late Pleistocene climates in the southern Levant and its neighboring deserts, Global Planet. Change, 60, 165-192, 2008.

Essallami, L., Sicre, M. A., Kallel, N., Labeyrie, L., and Siani, G.: Hydrological changes in the Mediterranean Sea over the last 30,000 years, Geochem. Geophy. Geosy., 8, Q07002, doi:10.1029/2007GC001587, 2007. 
Felis, T., Lohmann, G., Kuhnert, H., Lorenz, S. J., Sholz, D., Pätzold, J., Al-Rousan, S. A., and Al-Moghrabi, S. M.: Increased seasonality in Middle East temperatures during the last interglacial period, Nature, 429, 164-168, 2004.

Fleitmann, D. and Matter, A.: The speleothem record of climate variability in Southern Arabia, C. R. Geosci., 341, 634-642, 2009.

Frumkin, A., Ford, D. C., and Schwarcz, H. P.: Continental oxygen isotopic record of the last 170,000 years in Jerusalem, Quaternary Res., 51, 317-327, 1999.

Frumkin, A., Bar-Yosef, O., and Schwartz, H. P.: Possible paleohydrological and paleoclimatic effects on hominin migration to and occupation of the Levant between MIS 6 and MIS 4, J. Human Evol., 60, 437-451, 2011.

Gasse, F.: Hydrological changes in the African tropics since the last glacial maximum, Quaternary Sci. Rev., 19, 189-211, 2000.

Guiot, J., Torre, F., Cheddadi, R., Peyron, O., Tarasov, P., Jolly, D., and Kaplan, J. O.: The climate of the Mediterranean Basin and of Eurasia of the Last Glacial Maximum as reconstructed by inverse vegetation modelling and pollen data, Ecologia Mediterranea, 25, 193-204, 1999.

Hajar, L., Khater, C., and Cheddadi, R.: Vegetation changes during the late Pleistocene and Holocene in Lebanon: a pollen record from the Bekaa Valley, Holocene, 18, 1089-1099, 2008.

Hajar, L., Haïdar-Boustani, M., Khater, C., and Cheddadi, R.: Environmental changes in Lebanon during the Holocene: Man vs. climate impacts, J. Arid Environ., 74, 746-755, 2010.

Hakim, B.: Recherches hydrologiques et hydrochimiques sur quelques karsts méditerranéens, Liban, Syrie et Maroc, Université Libanaise, Section des Etudes Géographiques II, Beyrouth, 1985.

Hazan, N., Stein, M., Agnon, A., Marco, S., Nadel, D., Negendank, J. F. W., Schwab, M. J., and Neev, D.: The late Quaternary limnological history of Lake Kinneret (Sea of Galilee), Israel, Quaternary Res., 63, 60-77, 2005.

Hoelzmann, P., Gasse, F., Dupont, L. M., Salzmann, U., Staubwasser, M., Leuchner, D. C., and Sirocko, F.: Palaeoenvironmental changes in the arid and subarid belt (Sahara-Sahel-Arabian Peninsula) from $150 \mathrm{ka}$ to present, in: Past Climate through Europe and Africa, edited by: Battarbee, R. W., Gasse, F., and Stickley, C. S., Springer, Dordrecht, 219-256, 2004.

Imbrie, J., Hays, J. D., Martinson, D. G., Mcintyre, A., Mix, A. C., Morley, J. J., Pisias, N. G., Prell, W. L., and Shackleton, N. J.: The orbital theory of Pleistocene climate: support from revised chronology of the marine $\delta^{18} \mathrm{O}$ record, Reidel, Dordrecht, 1984.

Kahana, R., Ziv, B., Enzel, Y., and Dayan, U.: Synoptic climatology of major floods in the Negev desert, Israel, Int. J. Climatol., 22, 867-882, 2002.

Kolodny, Y., Stein, M., and Machlus, M.: Sea-rain-lake relation in the Last Glacial East Mediterranean revealed by $\delta^{18} \mathrm{O}-\delta^{13} \mathrm{C}$ in Lake Lisan aragonites, Geochim. Cosmochim. Acta, 69, 40454060, 2005.

Kroon, D., Alexandser, I., Little, M., Lourens, L. J., Mattthewson, A., Robertson, A. H. F., and Sakamoto, T.: Oxygen isotope and sapropel stratigraphy in the Eastern Mediterranean during the last 3.2 millions years, Ocean Drilling Program Scientific Results, 160, College Station, Texas, 181-190, 1998.
Kuhlemann, J., Rohling, E. J., Krumrei, I., Kubik, P., Ivy-Ochs, S., and Kucera, M.: Regional synthesis of Mediterranean atmospheric circulation during the Last Glacial Maximum, Science, 231, 1338-1340, 2008.

Laîné, A., Kageyama, M., Salas-Mélia, D., Voldoire, A., Rivière, G., Ramstein, G., Planton, S., Tyteca, S., and Peterschmitt, J. Y.: Northern hemisphere storm tracks during the last glacial maximum in the PMIP2 ocean-atmosphere coupled models: energetic study, seasonal cycle, precipitation, Clim. Dynam., 32, 593-614, doi:10.1007/s00382-008-0391-9, 2009.

Langgut, D., Almogi-Labin, A., Bar-Matthews, M., and WeinsteinEvron, M.: Vegetation and Climate changes in the Eastern Mediterranean during the last glacial-interglacial cycle: new marine pollen core evidence for the last $86 \mathrm{ka}$, accepted for publication in Quaternary Sci. Rev., 2011.

Le Pichon, X. and Gaulier, J. M.: The rotation of Arabia and the Levant fault system, Tectonophysics, 153, 271-294, 1988.

Lézine, A.-M., von Grafenstein, U., Andersen, N., Belchemeri, S., Bordon, A., Caron, B., Cazet, J.-P., Erlenkeuser, H., Fouache, E., Grenier, C., Huntsman-Mapila, P., Huzeau-Mazaudier, D., Manelli, D., Mazaud, A., Robert, C., Sulpizio, R., Tiercelin, J.-J., Zanchetta, G., and Zeqolari, Z.: Lake Ohrid, Albania, provides an exceptional multi-proxy record of environmental changes during the last glacial-interglacial cycle, Palaeogeogr. Palaeocl., 287, 116-127, 2010.

Li, C. and Battisti, D. S.: Reduced Atlantic storminess during the Last Galcial Maximum: evidence from a coupled climate model, J. Climate, 21, 3561-3579, 2008.

Lisker, S., Vaks, A., Bar-Matthews, M., Porat, R., and Frumkin, A.: Stromatolites in caves of the Dead Sea Fault Escarpment: implications to latest Pleistocene lake levels and tectonic subsidence, Quaternary Sci. Rev., 28, 80-92, doi:10.1016/j.quascirev.2008.10.015, 2008.

Lisker, S., Vaks, A., and Bar-Matthews, M.: Late Pleistocene palaeoclimatic and palaeoenvironmental reconstruction of the Dead Sea area (Israel), based on speleothems and cave stromatolites, Quaternary Sci. Rev., 29, 1201-1211, doi:10.1016/j.quascirev.2010.01.018, 2010.

Magny, M.: Lake level studies: West-Central-Europe, Encyclopedia of Quaternary Science, 2. Amsterdam, Elsevier, 1389-1399, 2007.

Mangerud, Y., Jakobsson, M., Alexanderson, H., Astakhov, V. I., Clarke, K. C., Henriksen, M., Hjort, C., Krinner, G., Lunkka, J., Möller, P., Murray, A., Nikolskaya, O., Saarnisto, M., and Svenden, J. A.: Ice-damned lakes and rerouting of ice drainage of northern Eurasia during the Last Glaciation, Quaternary Sci. Rev., 23, 1313-1332, doi:10.1016/j.quascirev.2003.12.009, 2004.

Martinson, D. G., Pisias, N. G., Hays, J. D., Imbrie, J., Moore Jr., T. C., and Shackleton, N. J.: Age dating and the orbital theory of the Ice Ages: development of a high-resolution 0 to 300,000-year chronostratigraphy, Quaternary Res., 27, 1-29, 1987.

McGarry, S., Bar-Matthews, M., Matthews, A., Vaks, A., Schilman, B., and Ayalon, A.: Constraints on hydrological and paleotemperature variations in the Eastern Mediterranean region in the last $140 \mathrm{ka}$ given by the $\mathrm{D}$ values of speleothems fluid inclusions, Quaternary Sci. Rev., 23, 919-934, doi:10.1016/j.quascirev.2003.06.020, 2004. 
Meadows, J.: The Younger Dryas episode and the radiocarbon chronologies of the Lake Huleh and Ghab Valley pollen diagrams, Israel and Syria, Holocene, 15, 631-636, doi:10.1191/0959683605hl838fa, 2005.

Migowski, C., Stein, M., Prasad, S., Negendank, J. F. W., and Agnon, A.: Holocene climate variability and cultural evolution in the Near East from the Dead Sea sedimentary record, Quaternary Res., 66, 421-431, 2006.

Paillard, D., Labeyrie, L., and Yiou, P.: Macintosh program performs term-series analysis, Eos Trans. AGU, 77, 379, 1996.

Peyron, O., Goring, S., Dormoy, I., Kotthoff, U., Pross, J., de Beaulieu, J.-L., Drescher-Schneider, R., Vannière, B., and Magny, M.: Holocene seasonality changes in the central Mediterranean region reconstructed from the pollen sequences of Lake Accesa (Italy) and Tenaghi Philippon (Greece), Holocene, 21, 131-146, doi:10.1177/0959683610384162, 2011.

Raible, C. C., Ziv, B., Saaroni, H., and Wild, M.: Winter synopticscale variability over the Mediterranean Basin under future climate conditions as simulated by the ECHAM5, Clim. Dynam., 35, 473-488, doi:10.1007/s00382-009-0678-5, 2010.

Reille, M.: Pollen et spores d'Europe et d'Afrique du Nord, Laboratoire de botanique historique et de palynologie, Marseille, 1992.

Reimer, P. J., Baillie, M. G. L., Bard, E., Bayliss, A., Beck, J. W., Blackwell, P. G., Ramsey, C. B., Buck, C. E., Burr, G. S., Edwards, R. L, Friedrich, M., Grootes, P. M., Guilderson, T. P., Hajdas, I., Heaton, T. J., Hogg, A. G., Hughen, K. A., Kaiser, K. F., Kromer, B., McCormac, F. G., Mannong, S. W., Reimer, R. W., Richards, D. A., Southon, J. R., Talamo, S., Turney, C. S. M., van der Plicht, J., and Weyhenmeye, C. E.: INTERCAL09 and marine09 radiocarbon age and calibration curves, 0-50,000 years, Radiocarbon, 51, 1111-1150, 2009.

Roberts, N., Black, S., Boyer, P., Eastwood, W. J., Griffiths, H. I., Lamb, H. F., Leng, M. J., Parish, R., Reed, J. M., Twigg, D., and Yigitbasioglu, H.: Chronology and stratigraphy of Late Quaternary sediments in the Konya Basin, Turkey : results from the KOPAL Project, Quaternary Sci. Rev., 18, 611-630, 1999.

Robinson, S. A., Black, S., Sellwood, B. W., and Valdes, P. J.: A review of palaeoclimates and palaeoenvironments in the Levant and Eastern Mediterranean from 25,000 to 5000 years BP: setting the environmental background for the evolution of human civilisation, Quaternary Sci. Rev., 25, 1517-1541, doi:10.1016/j.quascirev.2006.02.006, 2006.

Rodwell, M. J. and Hopkins, B. J.: Monsoons and the dynamics of deserts, Q. J. Roy. Meteorol. Soc., 122, 1385-1404, doi:10.1002/qj.49712253408, 1996.

Rossignol-Strick, M. and Paterne, M.: A synthetic pollen record of the eastern Mediterranean sapropels of the last $1 \mathrm{Ma}$ : implication for the time-sacle and formation of sapropels, Mar. Geol., 153, 221-237, 1999 .

Rozanski, K.: Isotopes in atmospheric moisture, in: Isotopes in the Water Cycle: Past, Present and Future, a Developing Science, Springer, Dordrecht, 291-302, 2005.

Rozanski, K., Araguás-Araguás, L., and Gonfiantini, R.: Isotopic patterns in modern global precipitation, Climate Change in Continental Isotopic Records, Geophysical Monograph 78, American Geophysical Union, Washington, DC, 1-36, 1993.

Service Météorologique du Liban: Atlas climatique du Liban, Beirut, Lebanon, 1977.
Shafir, H. and Alpert, P.: Regional and local climatic effects on the Dead-Sea evaporation, Climatic Change, 105, 455-468, doi:10.1007/s10584-010-9892-8, 2010.

Sharon, D. and Kutiel, H.: The distribution of rainfall intensity in Israel, its regional and seasonal variations and its climatological evaluation, J. Climatol., 6, 277-291, 1986.

Shea, J. J.: Transitions or turnovers? Climatically-forced extinctions of Homo sapiens and Neanderthals in the east Mediterranean Levant, Quaternary Sci. Rev., 27, 2253-2270, doi:10.1016/j.quascirev.2008.08.015, 2008.

Stevens, L. R., Wright Jr., H. E., and Ito, E.: Proposed changes in seasonality of climate during the Lateglacial and Holocene at Lake Zeribar, Iran, Holocene, 11, 747, doi:10.1191/09596830195762, 2001

Stevens, L. R., Ito, E., Schwalb, A., Wright Jr., H. E.: Timing of atmospheric precipitation in the Zagros mountains inferred from a multi-proxy record from Lake Mirabad, Iran, Quaternary Res., 66, 494-500, 2006.

Svenden, J. A., Alexanderson, H., Astakhov, V. I., Demidov, I., Dowdeswell, J. A., Funder, S., Gataullin, V., Henriksen, M., Hjort, C., Houmark-Nielsen, M., Hubberten, H. W., Ingolfsson, O., Jakobsson, M., Kjær, K. H., Larsen, E., Lokrantz, H., Pekka Lunkka, J., Astrid Lysi, A., Mangerud, J., Matiouchkov, A., Murray, A., Möller, P., Niessen, P., Nikolskaya, O., Polyak, L., Saarnisto, M., Siegert, C., Siegert, M., Spielhagen, R. F., and Stein, R.: Late Quaternary ice sheet of northern Eurasia, Quaternary Sci. Rev., 13, 1229-1271, doi:10.1016/j.quascirev.2003.12.008, 2004.

Tarasov, P. E., Cheddadi, R., Guiot, J., Bottema, S., Peyron, O., Belmonte, J., Ruiz-Sanchez, V., Saadi, F., and Brewer, S.: A method to determine warm and cool steppe biomes from pollen data; application to the Mediterranean and Kazakhstan regions, J. Quatern. Sci., 13, 335-344, 1998.

Torfstein, A., Haase-Schramm, A., Waldmann, N., Kolodny, Y., and Stein, M.: U-series and oxygen isotope chronology of the mid-Pleistocene Lake Amora (Dead Sea basin), Geochim. Cosmochim. Acta, 73, 2603-2630, doi:10.1016/j.gca.2009.02.010, 2009.

Tzedakis, P. C.: Seven ambiguities in the Mediterranean palaeoenvironmental narrative, Quaternary Sci. Rev., 26, 2042-2066, doi:10.1016/j.quascirev.2007.03.014, 2007.

Tzedakis, P. C., Hooghiemstra, H., and Pälike, H.: The last 1.35 million years at Tenaghi Philippon, revised chronostratigraphy and long-term vegetation trends, Quaternary Sci. Rev., 25, 3416-3430, doi:10.1016/j.quascirev.2006.09.002, 2006.

Vaks, A., Bar-Matthews, M., Ayalon, A., Schilman, B., Gilmour, M., Hawkesworth, C. J., Frumkin, A., Kaufman, A., and Matthews, A.: Paleoclimate reconstruction based on the timing of speleothem growth and oxygen and carbon isotope composition in a cave located in the rainshadow in Israel, Quaternary Res., 59, 182-193, doi:10.1016/S0033-5894(03)00013-9, 2003.

Vaks, A., Bar-Matthews, M., Ayalon, A., Matthews, A., Frumkin, A., Dayan, U., Halicz, L., Almogi-Labin, A., and Schilman, B.: Paleoclimate and location of the border between Mediterranean climate region and the Saharo-Arabian Desert as revealed by speleothems from the northern Negev Desert, Israel, Earth Planet. Sc. Lett., 249, 384-399, doi:10.1016/j.eps1.2006.07.009, 2006. 
Vaks, A., Bar-Matthews, M., Ayalon, A., Matthews, A., Halicz, L., and Frumkin, A.: Desert speleothems reveal climatic window for African exodus of early modern humans, Geology, 35, 831-834, 2007.

Vaks, A., Bar-Matthews, M., Matthews, A., Ayalon, A., Matthews, A., and Frumkin, A.: Middle-Late Quaternary paleoclimate of northern margins of the Saharian-Arabian Desert: reconstruction from speleothems of Negev desert, Israel, Quaternary Sci. Rev., 29, 2647-2662, doi:10.1016/j.quascirev.2010.06.014, 2010.

Verheyden, S., Nader, F. H., Cheng, H. J., Edwards, L. R., and Swennen, R.: Paleoclimate reconstruction in the Levant region from the geochemistry of a Holocene stalagmite from the Jeita cave, Lebanon, Quaternary Res., 70, 368-381, 2008.

Waldmann, N., Stein, M., Ariztegui, D., and Starinsky, A.: Stratigraphy, depositional environments and level reconstructon of the last interglacial Lake Samra in the Dead Sea basin, Quaternary Res., 72, 1-15, 2009.

Waldmann, N., Torfstein, A., and Stein, M.: Northward intrusions of low- and mid-latitude storms across the SaharoArabian belt during past interglacials, Geology, 38, 567-570, doi:10.1130/G30654.1, 2010.

Weinstein-Evron, M.: The Paleoecology of the Early Wurm in the Hula Basin, Israel, Paléorient, 9, 5-19, 1983.
Weinstein-Evron, M., Vogel, J. C., and Kronfeld, J.: Further attempts at dating the palynological sequence of the Gula L07 core, upper Jordan Valley, Radiocarbon, 43, 561-570, 2001.

Yasuda, Y., Kitagawa, H., and Nakagawa, T.: The earliest record of major anthropogenic deforestation in the Ghab Valley, northwest Syria: a palynological study, Quatern. Int., 73/74, 127-136, 2000.

Ziegler, M., Tuenter, E., and Lourens, L. J.: The precession phase of the boreal summer monsoon as viewed from the eastern Mediterranean (ODP site 968), Quaternary Sci. Rev., 29, 1481-1490, doi:10.1016/j.quascirev.2010.03.011, 2010.

Ziv, B., Saaroni, H., and Alpert, P.: The factors governing the summer regime of the eastern Mediterranean, Int. J. Climatol., 24, 1859-1871, 2004.

Ziv, B., Dayan, U., Kuschnir, Y., Roth, C., and Enzel, Y.: Regional and global atmospheric patterns governing rainfall in the southern Levant, Int. J. Climatol., 26, 55-73, doi:10.1016/j.quascirev.2005.07.008, 2006.

Ziv, B., Saaroni, H., Romem, M., Heifetz, E., Harnik, N., and Baharad, A.: Analysis of conveyor belts in winter Mediterranean cyclones, Theor. Appl. Climatol., 99, 441-455, 2010. 